\title{
Transition Metal lons: Charge Carriers that Mediate the Electron Capture Dissociation Pathways of Peptides
}

\author{
Xiangfeng Chen, Yi Man Eva Fung, Wai Yi Kelly Chan, Pui Shuen Wong, Hoi Sze Yeung, \\ T.-W. Dominic Chan \\ Department of Chemistry, The Chinese University of Hong Kong, Shatin, N.T., Hong Kong SAR, China
}

\begin{abstract}
Electron capture dissociation (ECD) of model peptides adducted with first row divalent transition metal ions, including $\mathrm{Mn}^{2+}, \mathrm{Fe}^{2+}, \mathrm{Co}^{2+}, \mathrm{Ni}^{2+}, \mathrm{Cu}^{2+}$, and $\mathrm{Zn}^{2+}$, were investigated. Model peptides with general sequence of ZGGGXGGGZ were used as probes to unveil the ECD mechanism of metalated peptides, where $\mathrm{X}$ is either $\mathrm{V}$ or $\mathrm{W}$; and $\mathrm{Z}$ is either $\mathrm{R}$ or $\mathrm{N}$. Peptides metalated with different divalent transition metal ions were found to generate different ECD tandem mass spectra. ECD spectra of peptides metalated by $\mathrm{Mn}^{2+}$ and $\mathrm{Zn}^{2+}$ were similar to those generated by ECD of peptides adducted with alkaline earth metal ions. Series of $c$-/z-type fragment ions with and without metal ions were observed. $\mathrm{ECD}$ of $\mathrm{Fe}^{2+}, \mathrm{Co}^{2+}$, and $\mathrm{Ni}^{2+}$ adducted peptides yielded abundant metalated $a$-/y-type fragment ions; whereas ECD of $\mathrm{Cu}^{2+}$ adducted peptides generated predominantly metalated $b$-/y-type fragment ions. From the present experimental results, it was postulated that electronic configuration of metal ions is an important factor in determining the ECD behavior of the metalated peptides. Due presumably to the stability of the electronic configuration, metal ions with fully-filled (i.e., $\mathrm{Zn}^{2+}$ ) and half filled (i.e., $\mathrm{Mn}^{2+}$ ) d-orbitals might not capture the incoming electron. Dissociation of the metal ions adducted peptides would proceed through the usual ECD channel(s) via "hot-hydrogen" or "superbase" intermediates, to form series of $c-/ z^{\bullet}$ - fragments. For other transition metal ions studied, reduction of the metal ions might occur preferentially. The energy liberated by the metal ion reduction would provide enough internal energy to generate the "slow-heating" type of fragment ions, i.e., metalated $a-/ y$ fragments and metalated $b$ - $y$ - fragments.
\end{abstract}

Key words: Electron capture dissociation, Transition metal ions, Peptides, Fragmentation, Electronic configuration

\section{Introduction}

E lectron capture dissociation (ECD) [1] has drawn much $\checkmark$ attention in the past decade because of its wide application in peptide/protein structural analysis. After capturing a low-energy electron, the multiply-charged peptide/protein ion undergoes radical initiated dissociation. ECD of protonated peptides mainly produces $c$ - $/ z^{*}$-type fragment ions via the cleavage of $\mathrm{N}-\mathrm{C}_{\alpha}$ bonds along the

Correspondence to: T.-W. D. Chan; e-mail: twdchan@cuhk.edu.hk peptide backbone $[2,3]$. In contrast to those "slow-heating" dissociation methods [4-7], ECD does not affect noncovalent linkages and post-translational modifications (PTMs). As a complementary tool for conventional MS/ MS methods, ECD has been used for de Novo sequencing of novel proteins [8], PTMs localization and characterization [9-14], and tertiary structure analysis of peptides/proteins in gas phase [15-17].

Despite the variety of applications, the performance of ECD is still not satisfactory [18, 19]. For instance, the ECD efficiency of dications in practice is typically lower than $20 \%$. In addition, some natural moieties [20] and PTMs [21] 
were found to suppress or even inhibit the backbone fragmentation after electron capture event.

With the diverse reactivity of transition metal ions in gas phase [22], ECD of peptides adducted with transition metal ions might provide complementary sequence information as compared to that of the protonated peptides. Many previous studies have investigated the ECD of biomolecules and model peptides adducted with metal ions [23-33]. The key questions in ECD of metal ion peptide complexes are the electron neutralization site(s) and the determining factor(s) for various fragmentations. For alkali metal ions and alkaline earth metal ions adducted peptides, metalated $c-/ z$-type fragment ions were produced exclusively [23, 24]. Williams and co-workers concluded that the incoming electron tended to neutralize the cation of higher recombination energy [23]. Our group suggested that the incoming electron was captured by the mobile proton, rather than the metal ions. The metal ions did not seem to play any significant roles in the dissociation process [24]. Regarding the transition metal ions adducted peptides, Heck et al. classified their ECD behavior as typical $\left(_{\mathrm{Ni}^{2+}}, \mathrm{Co}^{2+}\right.$, and $\left.\mathrm{Zn}^{2+}\right)$ and atypical $\left(\mathrm{Cu}^{2+}\right)$ by examining the types of ECD fragment ions [25]. The authors postulated that the electron was initially captured by metal ion and then transferred to the peptides to induce both typical and atypical ECD fragment ions. By studying the ECD of metal ion and proton co-adducted substance P (SubP) trications, Håkansson et al. claimed that the electron transfer from metal ions to the peptide moiety could be correlated with the second ionization energies of metal atoms [26]. Yuri and coworkers attributed the different cleavage patterns obtained from ECD of peptides adducted with different metal ions to the conformational changes of the model peptides [27]. ECD of histidine-containing and methionine-containing peptides adducted with platinum ions were investigated by O'Hair and co-workers [28]. No radical-type backbone fragment ions were observed. Only some platinum ions adducted $a$-, $b$-, and $y$-ions were occasionally observed. More recently, our group observed peptide radical cation $\left(\mathrm{M}^{+\cdot}\right)$ and fragment ions corresponding to neutral side chain losses from $\mathrm{M}^{+\cdot}$ in the ECD spectra of $\mathrm{Cd}^{2+}$ and $\mathrm{Hg}^{2+}$ adducted peptides [29]. The experimental results were rationalized by a two-step process involving an initial charge reduction the metal ions by the incoming electron and then an electron transfer from the peptide moiety to the charge reduced metal ions.

Due presumably to the presence of some amino acid residues with strong metal-anchoring properties, some metalated peptides were found to undergo specific side chain losses under typical ECD conditions [26, 33]. This type of product ions may be recognized as diagnostic marker ions for the existence of specific amino acid residues. However, these preferential side chain loss reactions might also limit the generation of sequence ions and thus concealing the ECD behaviors of different metalated peptide ions. For instance, ECD of $\mathrm{Ni}^{2+}$ and proton coadducted SubP trications induced mainly side chain loss of methionine, and generated limited sequence specific fragment ions [26].
In this study, we studied the ECD behavior of several model peptides adducted with different divalent transition metal ions, including $\mathrm{Mn}^{2+}, \mathrm{Fe}^{2+}, \mathrm{Co}^{2+}, \mathrm{Ni}^{2+}, \mathrm{Cu}^{2+}$, and $\mathrm{Zn}^{2+}$. Table 1 summarizes the ionization energies, electronic configurations and coordination chemistries of these first row divalent transition metal ions. Model peptides with a general sequence of ZGGGXGGGZ, where $\mathrm{X}$ is either $\mathrm{V}$ or $\mathrm{W}$; and $\mathrm{Z}$ is either $\mathrm{R}$, or $\mathrm{N}$, were used. The use of these model peptides, as opposed to the use of bioactive peptides, was to reduce the complexity of the spectra. The inclusion of two basic amino acids $(Z)$ in the model peptides allowed the acquisition of ECD spectra of the corresponding doubly-protonated peptide species for direct spectral comparison. Glycine spacers were used to separate functionalized amino acid residues and to provide a frame with relatively high flexibility.

\section{Experimental}

\section{Sample Preparation}

All materials were obtained commercially and were used without further purification. Manganese (II) acetate and copper (II) acetate were obtained from Beijing HuaGongChang (Beijing, China); cobalt (II) acetate, nickel (II) acetate and zinc (II) acetate were obtained from Riedel-de Haën (Seelze, Germany); Iron (II) chloride was obtained from Sigma Company (St. Louis, MO, USA). Methanol was purchased from Labscan Ltd. (Bangkok, Thailand). Model peptides were custom-synthesized by Peptron Inc., (Daejeon, South Korea). The samples were prepared at concentrations of $1 \times 10^{-4}-2.5 \times 10^{-4} \mathrm{M}$ in 1:1 water-methanol. The concentrations of the metal salts were $5 \times 10^{-3} \mathrm{M}$ in peptide solutions.

\section{Instrumentation}

All experiments were performed by using a 4.7 Tesla FTMS system (APEX III; Bruker Instrument Inc., Boston, MA, USA). This instrument was equipped with a standard, commercially available external electrospray ion source (Analytica, Branford, CT, USA) [35]. The ESI ion source was modified to adopt a homemade nanospray assembly [36]. Eight to $10 \mu \mathrm{L}$ of sample solution was loaded into a tapered capillary tip, which was electrically grounded using a $15 \mu \mathrm{m}$ gold-plated tungsten wire. Intact molecular ions were produced. Ion transmission from the external source into the trapped ion cell was achieved by using a standard electrostatic lens system. The sidekick ion accumulation method was used to facilitate the ion trapping process. Ten cycles of multiple ions filling (MIF) were used to enhance the intensity of precursor ions [37]. In all experiments, static trapping potentials of $1.0 \mathrm{~V}$ were used. Initial calibration of the instrument was achieved by using a peptide mixture containing LGF, angiotensin II, and melittin. A standard electrically heated filament source was used to produce pulses of electron beam. The filament was made of rhenium 
Table 1. A Summary of the Physical and Chemical Information Related to the Selected Divalent Transition Metal Ions

\begin{tabular}{|c|c|c|c|c|c|c|c|c|c|c|}
\hline \multirow[t]{3}{*}{ Element } & \multirow[t]{3}{*}{ Symbol } & \multirow[t]{3}{*}{ IE1 $(\mathrm{eV})$} & \multirow[t]{3}{*}{ IE2 $(\mathrm{eV})$} & \multicolumn{4}{|c|}{ Electronic configuration } & \multicolumn{3}{|c|}{ Ionic radius $(\AA)^{\mathrm{c}}$} \\
\hline & & & & \multirow[t]{2}{*}{$\mathrm{M}^{2+}$} & \multicolumn{3}{|c|}{$\mathrm{M}^{+} \mathrm{a}$} & \multirow[t]{2}{*}{ 4-Coordinated } & \multirow[t]{2}{*}{ 6-Coordinated } & \multirow[t]{2}{*}{ 8-Coordinated } \\
\hline & & & & & Ground state & First excited state & $\Delta \mathrm{E} \mathrm{kJ} / \mathrm{mol}$ & & & \\
\hline Manganese & $\mathrm{Mn}$ & 7.5 & 15.6 & $3 d^{5}$ & $3 d^{5} 4 s^{1}$ & $3 d^{5} 4 s^{1}\left(3 d^{6}\right)^{b}$ & $112.9(174.5)^{\mathrm{b}}$ & 0.80 & $0.81(0.97)^{\mathrm{d}}$ & 1.10 \\
\hline Iron & $\mathrm{Fe}$ & 7.9 & 16.2 & $3 d^{6}$ & $3 d^{6} 4 s^{1}$ & $3 d^{7}$ & 24.1 & $0.77(0.78)^{\mathrm{e}}$ & $0.75(0.92)^{\mathrm{d}}$ & 1.06 \\
\hline Cobalt & Co & 7.9 & 17.1 & $3 d^{7}$ & $3 \mathrm{~d}^{8}$ & $3 d^{7} 4 s^{1}$ & 41.5 & 0.72 & $0.79(0.88)^{\mathrm{d}}$ & 1.04 \\
\hline Nickel & $\mathrm{Ni}$ & 7.6 & 18.2 & $3 \mathrm{~d}^{8}$ & $3 d^{9}$ & $3 d^{8} 4 s^{1}$ & 105.2 & $0.69(0.63)^{\mathrm{e}}$ & 0.83 & - \\
\hline Copper & $\mathrm{Cu}$ & 7.7 & 20.3 & $3 \mathrm{~d}^{9}$ & $3 \mathrm{~d}^{10}$ & $3 d^{9} 4 s^{1}$ & 271.1 & $0.71(0.71)^{\mathrm{e}}$ & 0.87 & - \\
\hline Zinc & $\mathrm{Zn}$ & 9.4 & 18.0 & $3 d^{10}$ & $3 \mathrm{~d}^{10} 4 \mathrm{~s}^{1}$ & - & - & 0.74 & 0.88 & 1.04 \\
\hline
\end{tabular}

${ }^{\mathrm{a}}$ Data obtained from Reference [34];

${ }^{\mathrm{b}} \mathrm{Second}$ excited state;

${ }^{\mathrm{c}}$ For doubly-charged species; data obtained from [26].

${ }^{\mathrm{d}}$ Values correspond to radii for low spin (high spin) electronic configurations;

${ }^{\mathrm{e}}$ Values correspond to radii for tetrahedral (square-planar) coordination.

ribbon and was fixed at a distance of $108 \mathrm{~mm}$ from the rear end of the Infinity cell. Details of the geometry of the filament source have been previously described [38]. Typical experimental conditions were 3.3 A filament heating current, 3.5 to $3.8 \mathrm{~V}$ average filament bias voltage, and 800 to $1000 \mathrm{~ms}$ electron irradiation time. All ECD mass spectra were acquired in broadband mode using 128 or $256 \mathrm{~Kb}$ dataset. Thirty to 50 scans were normally summed to improve the signal-to-noise ratio. The time-domain signals were zero-filled once before Fourier transformation.

\section{Calculations}

All calculations were performed by using the Gaussian 03 package [39]. Equilibrium geometries were determined by full optimization followed by harmonic frequency calculations to confirm the nature of minima and transition states. All the stationary points were optimized using the Becke three parameter hybrid (B3LYP) exchange-correlation functional in the framework of the Kohn-Sham density functional theory (DFT) [40-42]. The standard split-valence basis set 6-31++G (d,p) was used for $\mathrm{H}, \mathrm{C}, \mathrm{N}$, and $\mathrm{O}$ atoms. All the metal cations were described by employing the Hay-Wadt effective core potential (ECP) with LANL2DZ basis set [43-45]. Single point energy calculations were performed at the B3LYP level in conjunction with LANL2DZ+6-311++G(3df,2p) basis set.

\section{Results and Discussion}

\section{ECD of Transition Metal Ions Adducted $R G G G V G G G R$}

Figure 1a-f present ECD spectra of RGGGVGGGR metalated by $\mathrm{Mn}^{2+}, \mathrm{Fe}^{2+}, \mathrm{Co}^{2+}, \mathrm{Ni}^{2+}, \mathrm{Cu}^{2+}$, and $\mathrm{Zn}^{2+}$, respectively. Sequence ions are labeled according to our previously proposed nomenclature, in which $\bar{c}$-and $\bar{z}$-denote the corresponding $\mathrm{N}$ - and $\mathrm{C}$-terminal fragments originated from the homolytic cleavage of the $\mathrm{N}-\mathrm{C}_{\alpha}$ linkage, respectively. Any surplus of proton/hydrogen atom or metal ion/atom is indicated in the label $[24,29]$. As summarized in the bond cleavage inserts, many sequence specific fragment ions were generated in the ECD spectra. The types of fragment ions and their distribution generated by peptides adducted with different transition metal ions were found to differ significantly from each others. It was interesting to find that nonmetalated fragment ions were observed in all ECD spectra of metal ions adducted peptides except for that of $\mathrm{Cu}^{2+}$. Among the selected transition metal ions, ECD of $\mathrm{Mn}^{2+}$ and $\mathrm{Zn}^{2+}$ adducted RGGGVGGGR triggered similar types of fragment ions compared to those observed for protonated and alkaline metal ions adducted peptides $[23,24]$. The abundances of fragment ions, however, were quite different.

For $\mathrm{Mn}^{2+}$ adducted peptide, three nonmetalated fragment ions, $\left[\bar{c}_{n}+2 \mathrm{H}\right]^{+}\left(n=4\right.$ and 5) and $\left[\bar{z}_{5}+\mathrm{H}\right]^{+}$, were generated. In addition to the protonated fragment ions, abundant metalated $c$-/z-type fragment ions were observed, among which $\left[\bar{c}_{5}+\mathrm{Mn}-\mathrm{H}\right]^{+}$was found to be the most intense fragment ions. In general, metalated $c$-type fragment ions were higher in abundance than the metalated $z$-type fragment ions, which was consistent with that of protonated peptide. Similar to ECD of alkaline earth metal ions adducted peptides, the $\left[\bar{c}_{n}+\mathrm{Mn}\right]^{+}$fragments were generally less abundant than the corresponding $\left[\bar{c}_{n}+\mathrm{Mn}-\mathrm{H}\right]^{+}$fragments. For the ECD spectrum of RGGGVGGGR adducted with $\mathrm{Fe}^{2+}$, a high proportion of the fragment ions $(\geq 70 \%)$ were protonated $c-/ z$ type fragment ions. Only some minor metalated $c$-ions, $\left[\bar{c}_{n}+\mathrm{Fe}-\mathrm{H}\right]^{+}(n=5-7)$ with the loss of $\mathrm{NH}_{3}$, were observed. The ECD fragment patterns for the $\mathrm{Co}^{2+}$ adducted peptide exhibited some differences as compared with those of $\mathrm{Mn}^{2+}$ and $\mathrm{Fe}^{2+}$. Apart from the protonated and metalated $c$ - and $z$ fragment ions, abundant metalated $a$-fragment ions were observed. The ECD spectrum of $\mathrm{Ni}^{2+}$-metalated RGGGVGGGR was dramatically different from those of other metal ions. Metalated $a$-type fragment ions and $y$-type fragment ions with concomitant $\mathrm{CO}_{2}$ loss were predominantly generated. Only one low intensity metalated $c$-ion and one protonated $c$ ion were observed. ECD of $\mathrm{Cu}^{2+}$-metalated peptide produced mainly metalated $b$ - and $y$-type fragment ions through the 
(a)

a.i.

$1.6 e+06$

$1.2 \mathrm{e}+06$

$8.0 e+05$

$4.0 e+05$

$0.0 \mathrm{e}+00$

200

(b)

a.i.
$1.6 e+06$
$1.2 e+06$
$8.0 e+05$
$4.0 e+05$
$0.0 e+00$

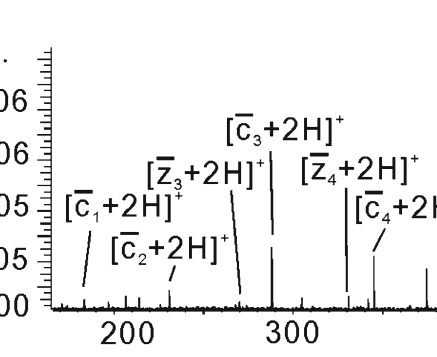

$[\mathrm{M}+\mathrm{Mn}]^{2+}$

$\left[\overline{\mathrm{c}}_{4}+\mathrm{Mn}-\mathrm{H}\right]^{+}+30 \mathrm{X}$ $\left[\overline{\mathrm{Z}}_{5}+\mathrm{Mn}\right]^{+} \quad\left[\overline{\mathrm{Z}}_{5}+2 \mathrm{H}\right]^{+}$

$\left.\left[\overline{\mathrm{C}}_{4}+2 \mathrm{H}\right]^{+}\right\rangle * \mid\left[\overline{\mathrm{C}}_{5}+2 \mathrm{H}\right]$ $\left[\overline{\mathrm{c}}_{3}+\mathrm{Mn}\right]^{+} \backslash\left[\overline{\mathrm{c}}_{5}+\mathrm{Mn}-\mathrm{H}\right]^{+}\left[\overline{\mathrm{c}}_{6}+\mathrm{Mn}-\mathrm{H}\right]^{+}$ $\left[\mathrm{Z}_{4}+2 \mathrm{H}\right]$

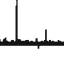
$\left[\begin{array}{c}{\left[\bar{z}_{6}+M n\right.} \\ \backslash\end{array} /\left[\bar{c}_{7}+M n-H\right]\right.$

$\left[\overline{\mathrm{z}}_{8}+\mathrm{Mn}-\mathrm{H}\right]^{+}$

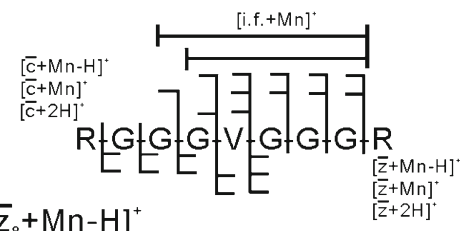

REGEGE VEGGGGTR

]$^{+}\left[\overline{\mathrm{C}}_{8}+\mathrm{Mn}\right]^{+}$

$[\mathrm{M}+\mathrm{Mn}-\mathrm{H}]^{+}$

500

600

700

$[\mathrm{M}+\mathrm{Fe}]^{2+}$

(c)

a.i.

a.i.
$2.0 \mathrm{e}+06$
$1.5 \mathrm{e}+06$
$1.0 \mathrm{e}+06$
$5.0 \mathrm{e}+05$
$0.0 \mathrm{e}+00$

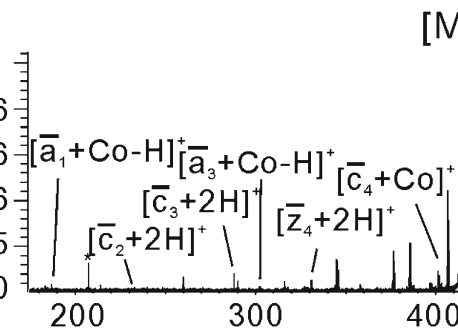

$[\mathrm{M}+\mathrm{Co}]^{2+}$

$-35 \mathrm{X}$

$\left[\overline{\mathrm{Z}}_{5}+2 \mathrm{H}\right]^{+}$

$\left[\overline{\mathrm{C}}_{5}+2 \mathrm{H}\right]^{+}$

$\left.\int\left[\overline{\mathrm{z}}_{6}+2 \mathrm{H}\right]^{+}{ }_{[} \overline{\mathrm{c}}_{6}+2 \mathrm{H}\right]^{+}\left[\overline{\mathrm{c}}_{7}+\mathrm{Fe}-\mathrm{H}\right]^{+}$

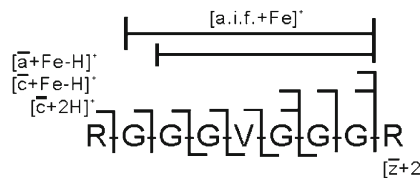

(d)

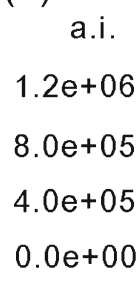

a.i.

$[\mathrm{M}+\mathrm{Ni}]^{2+}$

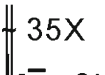

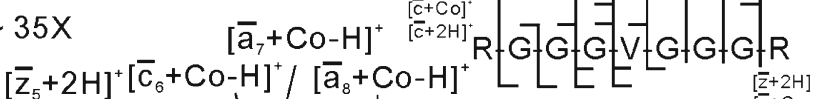
$\left[\overline{\mathrm{a}}_{8}+\mathrm{Fe}-\mathrm{H}\right]^{+}$

(e) a.i.

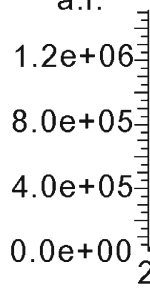

(f)
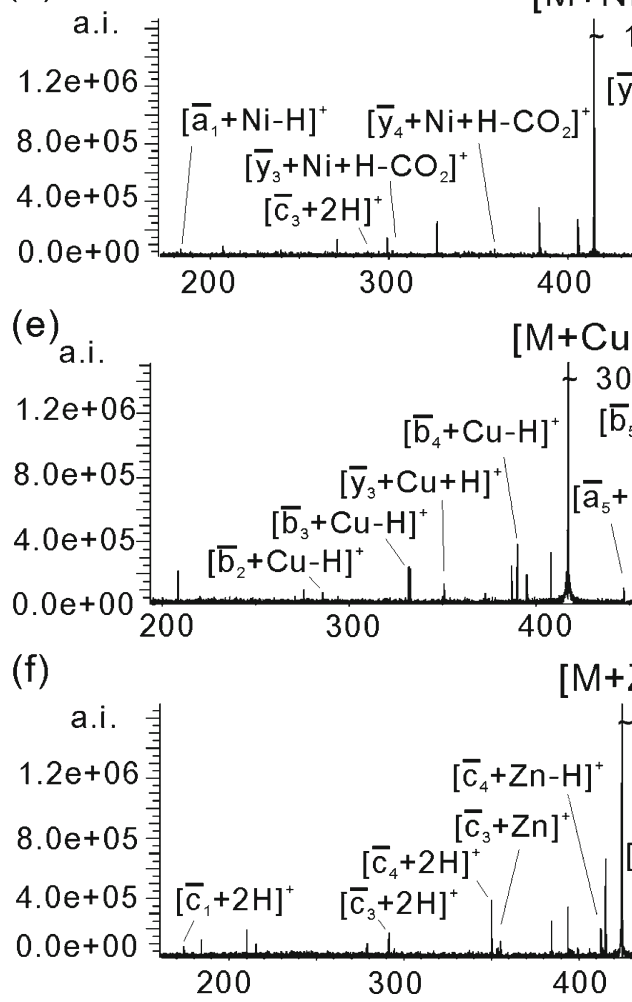

$-16 \mathrm{x}$ $\left[\overline{\mathrm{c}}_{5}+\mathrm{Co}-\mathrm{H}\right]^{+} /\left[\overline{\mathrm{c}}_{7}+\mathrm{Co}-\mathrm{H}\right]^{+}\left[\overline{\mathrm{z}}_{8}+\mathrm{Co}-\mathrm{H}\right]^{+}$ $\left.\left[\overline{\mathrm{c}}_{5}+2 \mathrm{H}\right]^{+}\right\rangle$

\begin{tabular}{lll}
$700 \quad 800 \mathrm{~m} / \mathrm{z}$ \\
\hline
\end{tabular}

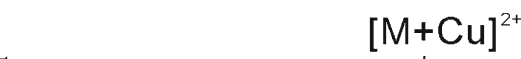

$\left[\overline{\mathrm{y}}_{5}+\mathrm{Ni}+\mathrm{H}-\mathrm{CO}_{2}\right]^{+}\left[\overline{\mathrm{y}}_{7}+\mathrm{Ni}+\mathrm{H}-\mathrm{CO}_{2}\right]$

$R \in G+G+G-V t G G G G G$
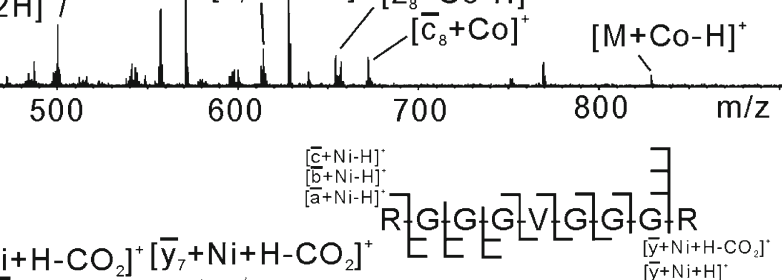

$\left[\overline{\mathrm{y}}_{6}+\mathrm{Ni}+\mathrm{H}-\mathrm{CO}_{2}\right]^{+} /\left[\overline{\mathrm{y}}_{8}+\mathrm{Ni}+\mathrm{H}-\mathrm{CO}_{2}\right]^{+} \quad\left[\mathrm{M}+\mathrm{Ni}-\mathrm{CO}_{2}\right]^{+}$

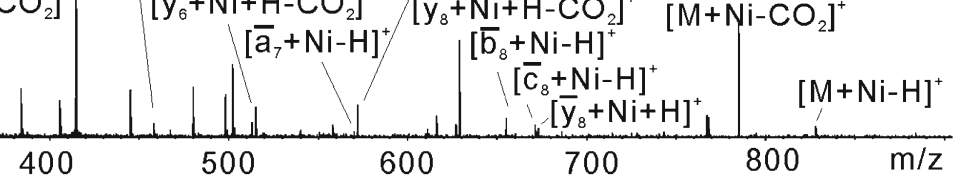

$\mathrm{M}+\mathrm{Cu}]^{2+}$

$\left.\left[\overline{\mathrm{b}}_{4}+\mathrm{Cu}-\mathrm{H}\right]^{+} \mid \begin{array}{l}30 \mathrm{X} \\ {\left[\overline{\mathrm{b}}_{5}+\mathrm{Cu}-\mathrm{H}\right]^{+}} \\ {\left[\overline{\mathrm{b}}_{7}+\mathrm{Cu}-\mathrm{H}\right]^{+}}\end{array} \overline{\mathrm{y}}_{7}+\mathrm{Cu}+\mathrm{H}\right]^{+}$

$R \in G G G G+V+G G G G G R$

$\left[\overline{\mathrm{y}}_{3}+\mathrm{Cu}+\mathrm{H}\right]^{+} \quad\left[\overline{\mathrm{a}}_{5}+\mathrm{Cu}-\mathrm{H}\right]^{+}{ }_{6}$

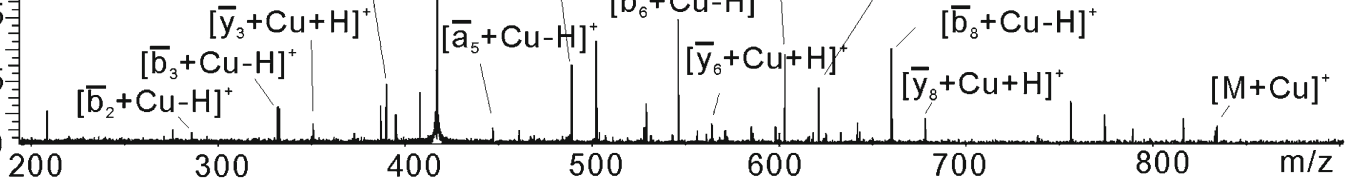

$[\mathrm{M}+\mathrm{Zn}]^{2+}$

$\left[\overline{\mathrm{Z}}_{\mathrm{T}}+\mathrm{Zn}-\mathrm{H}\right]^{+}+\left[\overline{\mathrm{Z}}_{7}+\mathrm{Zn}-\mathrm{H}\right]^{+}\left[\overline{\mathrm{c}}_{7}+\mathrm{Zn}-\mathrm{H}\right]^{+}$

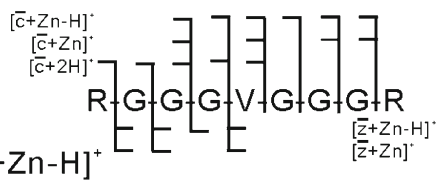

$\left[\overline{\mathrm{Z}}_{5}+\mathrm{Zn}-\mathrm{H}\right]^{+} \mid\left[\overline{\mathrm{c}}_{6}+\mathrm{Zn}-\mathrm{H}\right]^{+} /\left[\overline{\mathrm{z}}_{8}+\mathrm{Zn}-\mathrm{H}\right]^{+}$

$[\mathrm{M}+\mathrm{Zn}-\mathrm{H}]^{+}$

Figure 1. Typical ECD mass spectra of RGGGVGGGR metalated with (a) $\mathrm{Mn}^{2+}$, (b) $\mathrm{Fe}^{2+}$, (c) $\mathrm{Co}^{2+}$, (d) $\mathrm{Ni}^{2+}$, (e) $\mathrm{Cu}^{2+}$, and (f) $\mathrm{Zn}^{2+}$. "l.f." refers to the internal fragment ions

cleavages of the backbone amide linkages. ECD spectrum of $\mathrm{Zn}^{2+}$ adducted peptide was very similar to that of $\mathrm{Mn}^{2+}$. Mainly metalated $c-z$-type fragment ions, together with two nonmetalated $c$ - ions, were observed. 


\section{ECD of Transition Metal Ions Adducted $N G G G W G G G N$}

In order to investigate the importance of the zwitterionic form of the precursor ions on the ECD fragmentation pattern, a similar model peptide NGGGWGGGN was analyzed by using different metal ions as charge carriers. In this peptide sequence, non-basic polar asparagine residues were used instead of arginine residues. The absence of basic amino acid residues should suppress the deprotonation of the amide hydrogen. Figure $2 \mathrm{a}-\mathrm{f}$ present ECD spectra of NGGGWGGGN metalated by $\mathrm{Mn}^{2+}, \mathrm{Fe}^{2+}, \mathrm{Co}^{2+}, \mathrm{Ni}^{2+}, \mathrm{Cu}^{2+}$, and $\mathrm{Zn}^{2+}$, respectively. Consistent with the previous observations [24], no nonmetalated fragment ion was generated for all transition metal ions adducted NGGGWGGGN. All fragment ions observed in these spectra were metalated. Another noticeable difference between the two model peptides was that more internal fragment ions were produced in case of NGGGWGGGN. For $\mathrm{Mn}^{2+}, \mathrm{Co}^{2+}$, and $\mathrm{Zn}^{2+}$ adducted NGGGWGGGN precursor ions, considerably less metalated $c$ - and $z$-type fragment ions were observed in the ECD spectra compared to the corresponding metalated RGGGVGGGR. Among the selected metal ions, spectra of $\mathrm{Fe}^{2+}$ adducted peptide (i.e. ECD of $[\mathrm{Fe}$ $(\text { RGGGVGGGR) }]^{2+}$ versus [Fe(NGGGWGGGN)] ${ }^{2+}$ ) showed the largest differences. Mainly metalated $a$ - and $c$-type fragment ions, instead of protonated $c$-type ions, were observed. For $\mathrm{Ni}^{2+}$ adducted NGGGWGGGN, the types of fragment ions generated were similar to that of RGGGVGGGR. Mainly metalated $a$ - and $y$-type ions were observed. Similar to the spectrum of $\mathrm{Cu}^{2+}$ adducted RGGGVGGGR, metalated $b$ type fragment ions were generated in the ECD of $\mathrm{Cu}^{2+}$ adducted NGGGWGGGN.

\section{Formation of Nonmetalated Fragments Ions}

The formation of nonmetalated fragment ions in ECD of divalent metal ion adducted peptide dications is of fundamental and analytical interests. Such nonmetalated fragment ions generated by ECD of metalated peptides have been reported previously [24, 26, 29]. The formation of such protonated fragment ions indicates the existence of zwitterionic structures in the precursor ions. For the metal ion-peptide binary complex, the formation of zwitterionic structures requires deprotonation and re-protonation within the metal ion-peptide complex. The most favorable deprotonation sites of the model peptides studied here are the C-terminal carboxylic acid group $(-\mathrm{COOH})$ and the backbone amide $(\mathrm{NH})$ groups [46-49]. The side chains of the two basic amino acid residues and the $\mathrm{N}$ terminal amine group $\left(\mathrm{NH}_{2}\right)$ constitute the sites with highest proton affinities. They are believed to be the most possible reprotonation site(s) in the model peptides. To check the effects of the crucial functionalities on the formation of protonated fragment ions, the ECD spectra of some structural variants of RGGGVGGGR were obtained. Figure 3a-c show typical ECD spectra of $\mathrm{Mn}^{2+}$ metalated peptides as an example.
In order to investigate the effect of re-protonation sites on the formation of protonated fragment ions, two modified peptides, including replacement of $\mathrm{C}$-terminal arginine by aspargine and $\mathrm{N}$-acetylated of the $\mathrm{N}$-terminus were analyzed. The corresponding nonmetalated $c$-type fragmentation ions for the two modified peptides were similar to that of the unmodified peptide. It implies that replacing the C-terminal arginine and the N-terminus $\left(\mathrm{NH}_{2}\right)$ did not inhibit the formation of nonmetalated $c$-type fragment ions. Through amidating the $\mathrm{C}$-terminus, all protonated fragment ions were completely disappeared in the ECD spectrum of the metal ion adducted peptide. It indicates that the free C-terminal carboxylic acid site was essential for the formation of nonmetalated fragment ions.

Considering different conformers of the precursor ions [24], the incoming electron might selectively neutralize the mobile proton or the metal ions depending on the nature of metal ion-peptide complexes. For the singly zwitterionic precursor isomer, the formation of nonmetalated fragment ions could be interpreted based on the "superbase" mechanism [50]. The existing proton acts as the charge carrier for the fragment ions. Electron captured by the backbone $\pi^{*}$ orbital generates the anionic radical. Subsequently, the released energy might activate the complex to liberate another mobile proton via conformational changes of the metal peptide complex. The anionic radical might abstract the mobile proton to form the ketylamino radical and generate the nonmetalated fragment ions. For the doubly zwitterionic precursor isomer, the formation of nonmetalated fragment ions could be explained by either the "hot hydrogen atom" mechanism or the "superbase" mechanism. The absence of these fragment ions in ECD of $\mathrm{N}$ containing peptides was tentatively attributed to the low deprotonationreprotonation reactivies of metal ion-peptide complexes.

\section{Trends in ECD Fragmentation of Metalated Peptides}

Since different transition metal ion adducted peptides were found to generate different types of fragment ions, it might be informative to plot the relative contributions of different dissociation channels across the first row transition metal ions (i.e., the number of d-electrons). Three types of fragment ions were commonly found in the ECD spectra and were tentatively treated as originating from different dissociation channels. Type I fragments represent the characteristic fragment ions generated in ECD of protonated peptides. Since $c-/ z^{\bullet}$-type fragment ions are typical ECD fragment ions in the corresponding ECD spectra of protonated model peptides, we treated $c$ - and $z$-type fragment ions (with and without metal ions) as typical ECD fragment ions and were denoted as type I fragment ions. Type II fragments include metalated $a$ - and $y$-type fragment ions. Type III fragment ions represent the typical species formed in the CID of protonated peptides, including metalated $b$ - and $y$ type fragment ions. Since $y$-ions are formed in both Type II 

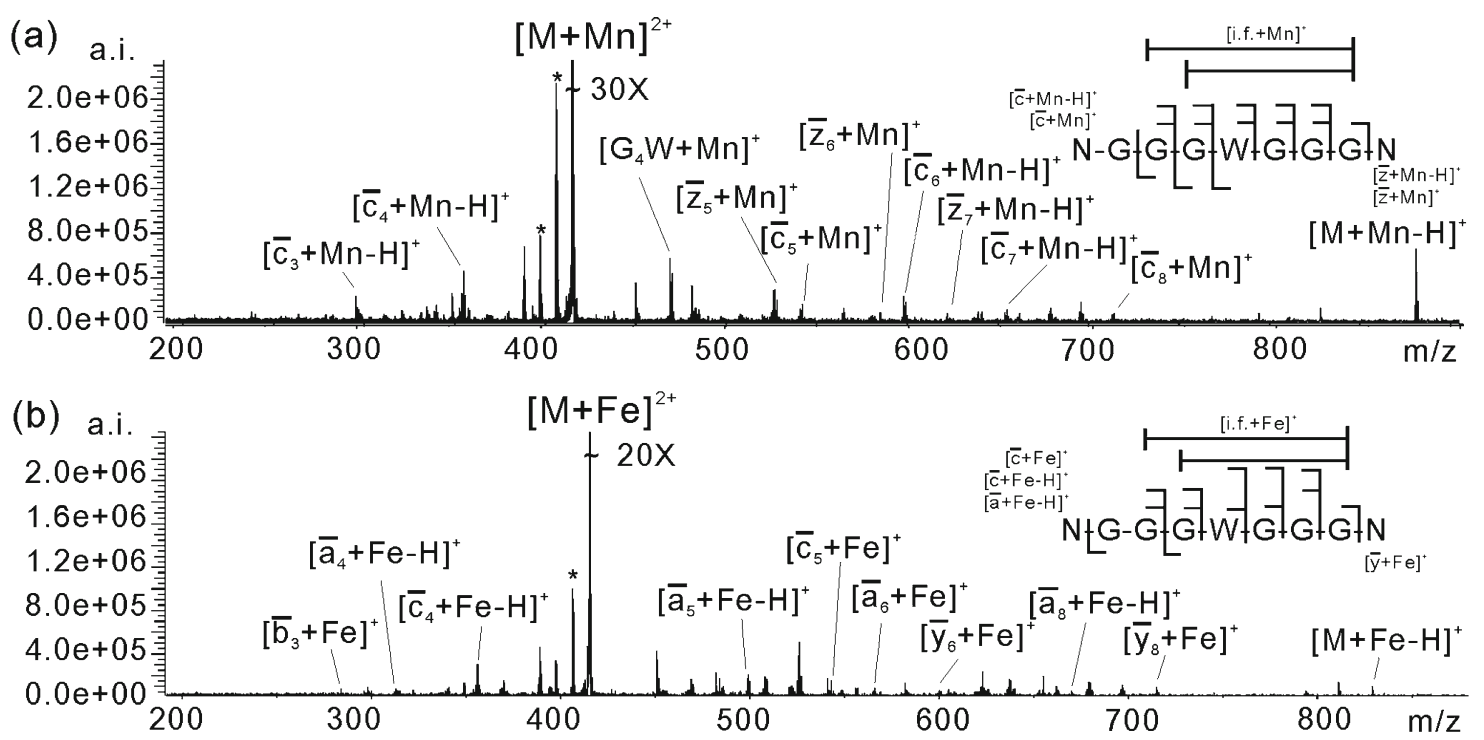

(c) a.i.
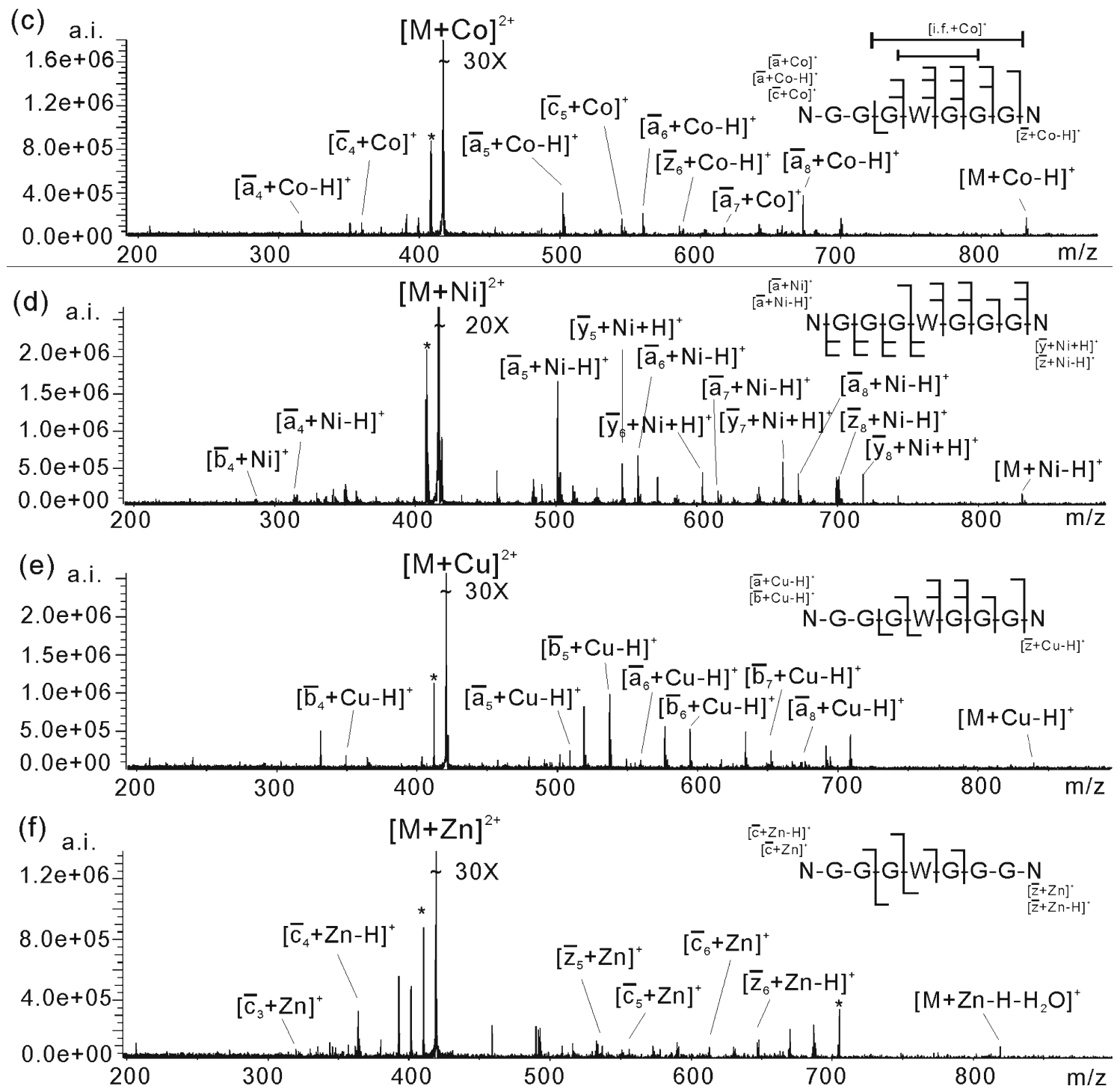

Figure 2. Typical ECD mass spectra of NGGGWGGGN metalated with (a) $\mathrm{Mn}^{2+}$, (b) $\mathrm{Fe}^{2+}$, (c) $\mathrm{Co}^{2+}$, (d) $\mathrm{Ni}^{2+}$, (e) $\mathrm{Cu}^{2+}$, and (f) $\mathrm{Zn}^{2+}$. "l.f." refers to the internal fragment ions 

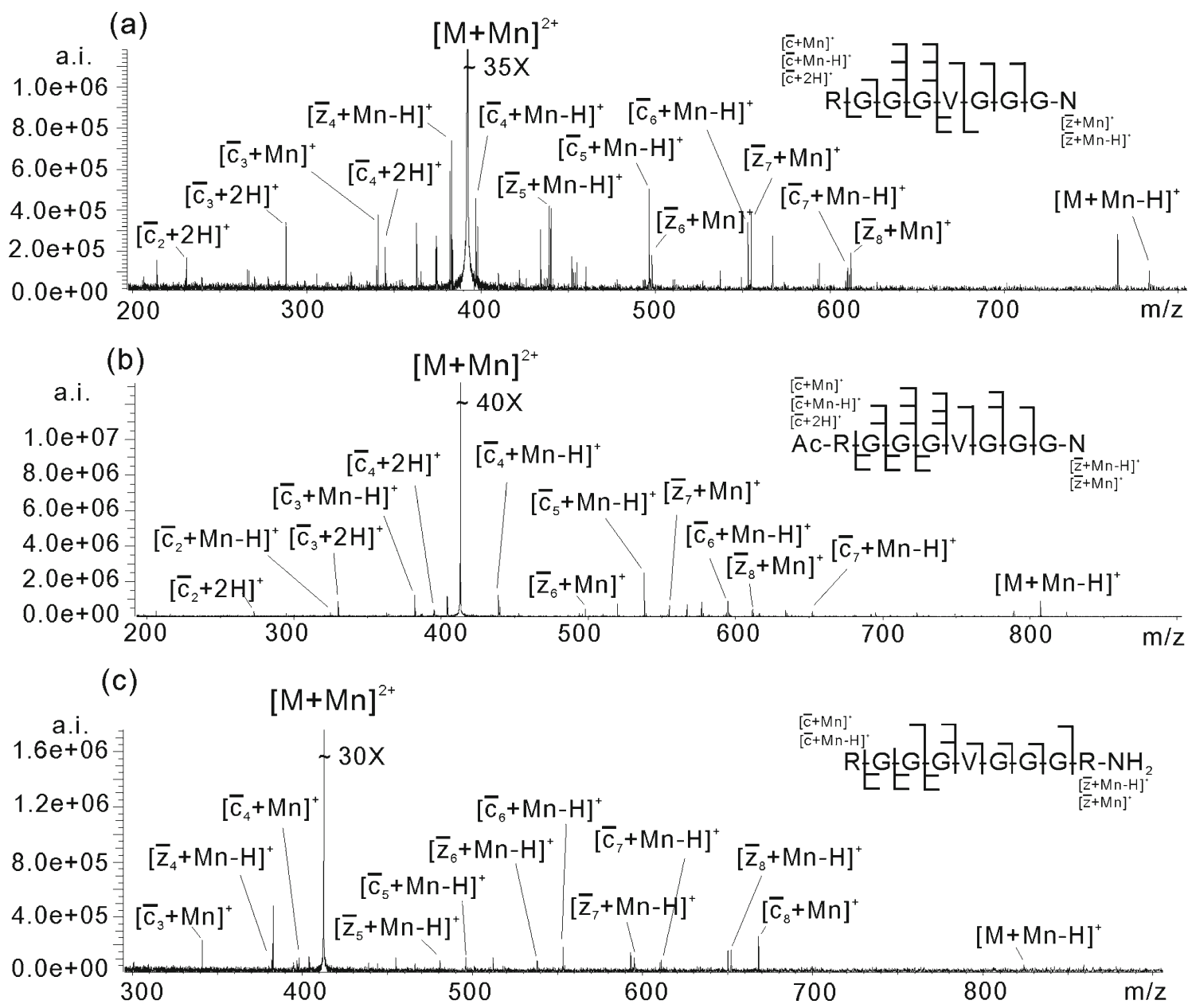

Figure 3. Typical ECD mass spectra of $\mathrm{Mn}^{2+}$ adducted (a) RGGGVGGGN, (b) RGGGVGGGR-NH ${ }_{2}$, and (c) Ac-RGGGVGGGN

and III fragment ions, its relative contribution to the abundances of type II and type III fragment ions were assumed to be proportional to the relative intensity of the corresponding $a$ - and $b$-type fragment ions. The product ion abundance (PIA) of each type of fragment ions was calculated using the Equation 1,

$$
\operatorname{PIA}(\text { type } \mathrm{X})=\frac{\sum(\%[\text { type } X])}{\sum(\%[\text { all fragment ions }])} \times 100 \%
$$

where $\mathrm{X}=\mathrm{I}$, II, or III.

Fragment ions intensity contributed by metastable dissociation under the present experimental conditions was eliminated by control experiments. The control experiments were acquired right after the acquisition of the normal ECD spectrum using the same tuning conditions and pulse program. Only the electron irradiation event was replaced by a decay of the same duration. The contribution made in non-electron irradiation conditions was subtracted from that of normal ECD experiment. Figure 4 shows the PIAs of various types of fragment ions in the ECD of different metal ion adducted RGGGWGGGR and NGGGWGGGN. It was interesting to note that the trends of the PIA(s) for different peptides were quite similar. Both $\mathrm{Mn}^{2+}$ and $\mathrm{Zn}^{2+}$ showed almost exclusively $c$-/z-type fragment ions (i.e., type I). The $c-/ z$-fragment ions intensities decrease progressively from $\mathrm{Mn}^{2+}$ to $\mathrm{Ni}^{2+}$ with a concomitant increase in the intensities of the $a$ - $/ y$-type fragment ions (Type II). Based on the present experimental result, it seemed that there was a progressive shift of the fragmentation channels when the model peptides were adducted with ions across the 1st row transition metals. In line with previous experiments [25-27], $\mathrm{Cu}^{2+}$ adducted peptide behaved rather differently. In all cases, ECD of $\mathrm{Cu}^{2+}$ adducted peptides showed mainly $b$ - $/ y$ type fragment ions.

It is also interesting to note that more type I fragment ions were generated in the ECD of the same metal ions adducted RGGGWGGGR than those of the metalated NGGGWGGGN. More type II fragment ions were generated in the ECD of metal ions adducted NGGGWGGGN compared with those of RGGGWGGGR.

\section{The Role of Precursor Ion Heterogeneity}

Precursor ion heterogeneity refers to distribution of canonical and zwitterionic forms of the precursor ions. We have 


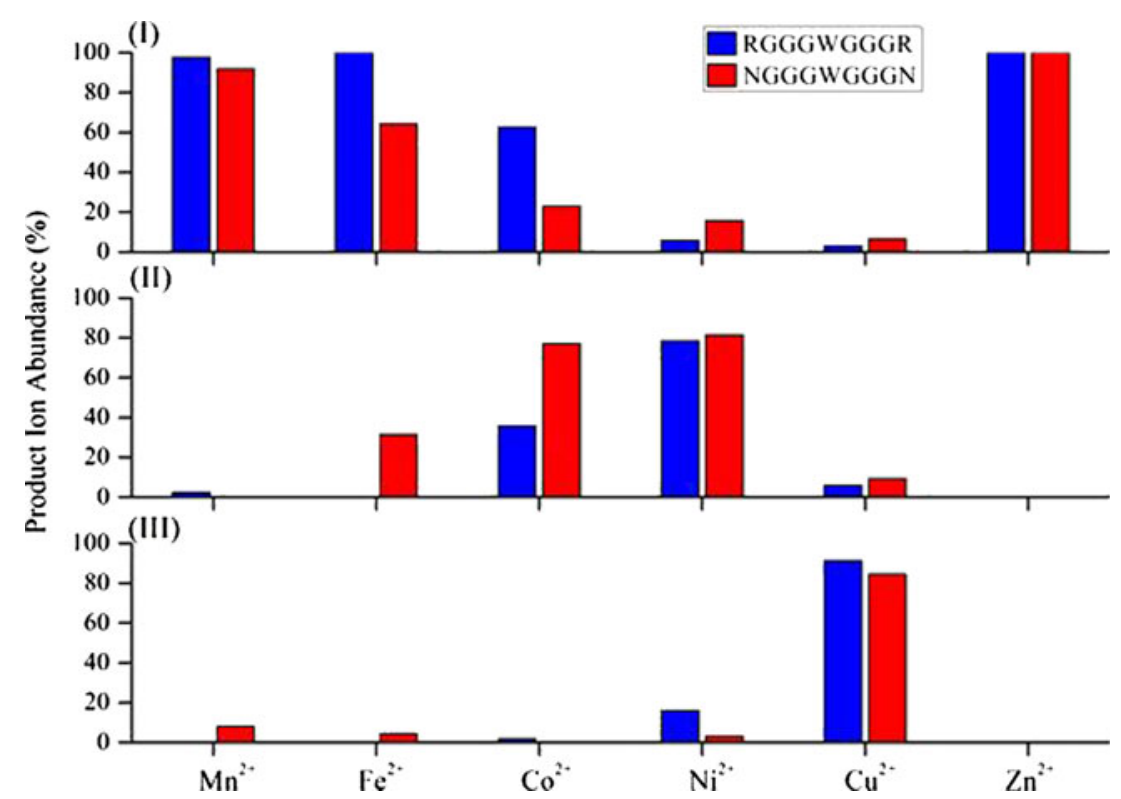

Figure 4. Product ion abundances (PIA) of metalated ZGGGWGGGZ $(Z=R$ and $N)$

previously demonstrated that the precursor ion heterogeneity was one of the important factors the affects the ECD fragmentation of peptides adducted with alkaline earth metal ions and group IIB metal ions [24, 29]. To explore the possible correlation between the precursor ion heterogeneity and the fragmentation behavior, the deprotonation reaction mediated by first row divalent transition metal ions were investigated computationally by using a truncated peptide model.

Because of the complexity of the system, it was not possible to fully explore and examine the stabilities of the full peptide structures along the potential energy surfaces using DFT methods. As a result, the peptide model and coordination of metal ions used here (Table 2) might not represent the entire candidate structures of peptides and coordination environment of metal ions. However, the structures and energetics reported here should provide useful information for qualitative estimation of the deprotonation reaction. N-methyl glycyl-glycinamide peptide model represents a canonical peptide with a free $\mathrm{N}$-terminal as proton acceptor. Based on the previous calculations of metal ionpoly(Gly) system [51, 52], the energies of zwitterionic structures with deprotonated C-terminal carboxylic acid are higher than that of canonical form, and thus the zwitterionic conformer was not considered here.

Scheme 1 shows the potential energy diagrams of deprotonation reaction mediated by first row transition metal ions. To reduce the complexity of the coordination mode, the stationary points $\left(\mathbf{A}, \mathbf{T} \mathbf{S}_{\mathrm{A}-\mathrm{B}}\right.$, and $\left.\mathbf{B}\right)$ adopt a conformation in which the metal ion $\left(\mathrm{Cat}^{2+}\right)$ was bi-coordinated by the carbonyl oxygen atoms. As shown in Scheme 1, the reactivities of intramolecular proton transfer reactions mediated by different metal ions were generally inversely proportional to the size of the metal ions except for $\mathrm{Cu}^{2+}$
(Table 1). For the deprotonation reactions mediated by $\mathrm{Fe}^{2+}$, $\mathrm{Co}^{2+}$, and $\mathrm{Ni}^{2+}$, the energy barriers for intra-molecular proton transfer were relatively lower and the reactions were calculated to be more exothermic compared to those of the other metal ions. It implies that peptides adducted with these transition metal ions might have larger population of zwitterionic conformers in precursor ion cloud than those of the peptide adducted with other transition metal ions. However, these metal ions showed different ECD behaviors as compared to that of protonated peptides. For the deprotonation reactions mediated by $\mathrm{Cu}^{2+}$, the energy barrier for proton transfer was relatively higher and the reaction was calculated to be more endothermic. The population of zwitterionic conformers in precursor ion cloud might be substantially lower than those of other transition metal ions. It was consistent with the fragmentation behavior of $\mathrm{Cu}^{2+}$ adducted peptide. Almost no typical ECD fragment ions were observed in the spectra of $\mathrm{Cu}^{2+}$ adducted peptides. $\mathrm{Mn}^{2+}$ and $\mathrm{Zn}^{2+}$ showed in-between deprotonation reactivities as compared with other metal ions. However, the fragment ions generated by ECD of these two metal ion adducted peptides were typical ECD fragment ions. Based on the calculated results, no direct correlation was found between the behavior of ECD of metalated peptides and the deprotonation reactivity.

\section{The Role of Electronic Configuration}

\section{Metal Ions with Fully and Half Filled d Shells: $\mathrm{Mn}^{2+}$ and $\mathrm{Zn}^{2+}$}

By comparing the ECD fragmentation of selected divalent transition metal ions with those of alkaline earth metal ions 
Table 2. Optimized Bond Distances $(\AA)$ for the Reactants, Transition States and Products Involved in the Deprotonation Reactions at the B3LYP/ LANL2DZ+6-31++G(d,p) Level

\begin{tabular}{|c|c|c|c|c|c|c|c|c|c|c|c|c|c|c|c|c|c|c|}
\hline \multirow[t]{2}{*}{$\mathrm{R}$} & \multicolumn{3}{|c|}{$\mathrm{Mn}^{2+}$} & \multicolumn{3}{|c|}{$\mathrm{Fe}^{2+}$} & \multicolumn{3}{|c|}{$\mathrm{Co}^{2+}$} & \multicolumn{3}{|c|}{$\mathrm{Ni}^{2+}$} & \multicolumn{3}{|c|}{$\mathrm{Cu}^{2+}$} & \multicolumn{3}{|c|}{$\mathrm{Zn}^{2+}$} \\
\hline & A & $\mathrm{TS}_{\mathrm{A}-\mathrm{B}}$ & B & A & $\mathrm{TS}_{\mathrm{A}-\mathrm{B}}$ & B & A & $\mathrm{TS}_{\mathrm{A}-\mathrm{B}}$ & B & A & $\mathrm{TS}_{\mathrm{A}-\mathrm{B}}$ & B & A & $\mathrm{TS}_{\mathrm{A}-\mathrm{B}}$ & B & A & $\mathrm{TS}_{\mathrm{A}-\mathrm{B}}$ & B \\
\hline $\mathrm{R}\left(\mathrm{H}^{1}-\mathrm{N}^{1}\right)$ & 1.958 & 1.308 & 1.052 & 1.948 & 1.327 & 1.048 & 1.954 & 1.329 & 1.476 & 1.963 & 1.327 & 1.045 & 2.210 & 1.329 & 1.042 & 1.938 & 1.318 & 1.050 \\
\hline $\mathrm{R}\left(\mathrm{H}^{1}-\mathrm{N}^{2}\right)$ & 1.039 & 1.297 & 1.892 & 1.041 & 1.281 & 1.930 & 1.041 & 1.279 & 1.937 & 1.041 & 1.280 & 1.971 & 1.022 & 1.276 & 2.014 & 1.041 & 1.288 & 1.912 \\
\hline $\mathrm{R}\left(\mathrm{C}^{1}-\mathrm{O}^{1}\right)$ & 1.284 & 1.294 & 1.314 & 1.288 & 1.298 & 1.321 & 1.287 & 1.297 & 1.321 & 1.288 & 1.293 & 1.323 & 1.254 & 1.283 & 1.302 & 1.286 & 1.297 & 1.320 \\
\hline$R\left(C^{1}-N^{2}\right)$ & 1.320 & 1.301 & 1.285 & 1.319 & 1.301 & 1.284 & 1.318 & 1.299 & 1.283 & 1.317 & 1.301 & 1.282 & 1.329 & 1.306 & 1.295 & 1.323 & 1.303 & 1.286 \\
\hline $\mathrm{R}\left(\mathrm{Cat}^{1}-\mathrm{O}^{1}\right)$ & 1.929 & 1.919 & 1.906 & 1.876 & 1.867 & 1.854 & 1.859 & 1.849 & 1.835 & 1.841 & 1.848 & 1.811 & 1.922 & 1.861 & 1.861 & 1.901 & 1.894 & 1.883 \\
\hline
\end{tabular}

[24], it was interesting to find that two of the selected metal ions, $\mathrm{Mn}^{2+}$ and $\mathrm{Zn}^{2+}$, behaved similarly as compared to alkaline earth metal ions. The studied alkaline earth metal ions, including $\mathrm{Mg}^{2+}, \mathrm{Ca}^{2+}, \mathrm{Sr}^{2+}$, and $\mathrm{Ba}^{2+}$, have the same valence electronic configuration of $\mathrm{s}^{0}$ occupations. As shown in Table 1, this is also true for $\mathrm{Zn}^{2+}$ ions, which has a $3 \mathrm{~d}^{10} 4 \mathrm{~s}^{0}$ electronic configuration. Although the outmost electron orbital of $\mathrm{Mn}^{2+}$ is not fully filled, it has half-filled dshell $\left(3 \mathrm{~d}^{5}\right)$. The common feature of these metal ions is that the outmost orbitals are relative stable (half-filled or fullyfilled). Previously, we postulated that alkaline earth metal ions reduction under the current electron capture dissociation conditions did not play any significant role in inducing fragmentations [24]. We believed that it was also true for $\mathrm{Mn}^{2+}$ - and $\mathrm{Zn}^{2+}$-adducted peptides. Because of their fullyfilled or half-filled $\mathrm{d}$ shells, trapping of an electron in the $3 \mathrm{~d}$ orbital was not favorable. If metal ion-electron recombination occurs, the incoming electron needs to occupy the $4 \mathrm{~s}$ orbital with slightly higher energy. The corresponding ground state electron configurations for $\mathrm{Mn}^{2+}$ and $\mathrm{Zn}^{2+}$ after charge reduction are high spin electronic configuration,
$3 d^{5} 4 s^{1}$, and $3 d^{10} 4 s^{1}$, respectively. Occupation of $4 s$ orbital results in an increase in Pauli repulsion between the metal ions and coordinated peptides. In addition, the occupied $4 \mathrm{~s}$ orbital prevents attractive binding interactions with the metal $3 \mathrm{~d}$ electrons. Due to the existence of a mobile proton liberated by metal ion coordination, it was proposed that the electron would be captured by the mobile proton (and/or backbone amide $\pi^{*}$ ) to trigger the usual ECD dissociation channel(s) via "hot-hydrogen" (or "superbase") intermediates to form series of $c$-/z-type fragment ions. This explained the observation of $c$-/z-type fragment ions which resembles the ECD spectra of protonated species.

\section{Metal Ions with Partially Filled d Shells: $\mathrm{Fe}^{2+}$, $\mathrm{Co}^{2+}, \mathrm{Ni}^{2+}$ and $\mathrm{Cu}^{2+}$}

For $\mathrm{Fe}^{2+}, \mathrm{Co}^{2+}$, and $\mathrm{Ni}^{2+}$, their outmost orbitals are neither half nor fully filled. For $\mathrm{Co}^{2+}$ and $\mathrm{Ni}^{2+}$, adoption of an electron into their outmost orbitals would lead to ground state electronic configuration of $3 \mathrm{~d}^{n}$ ( $n=8$ and 9, respectively). The striking similarity of these metal ions is that

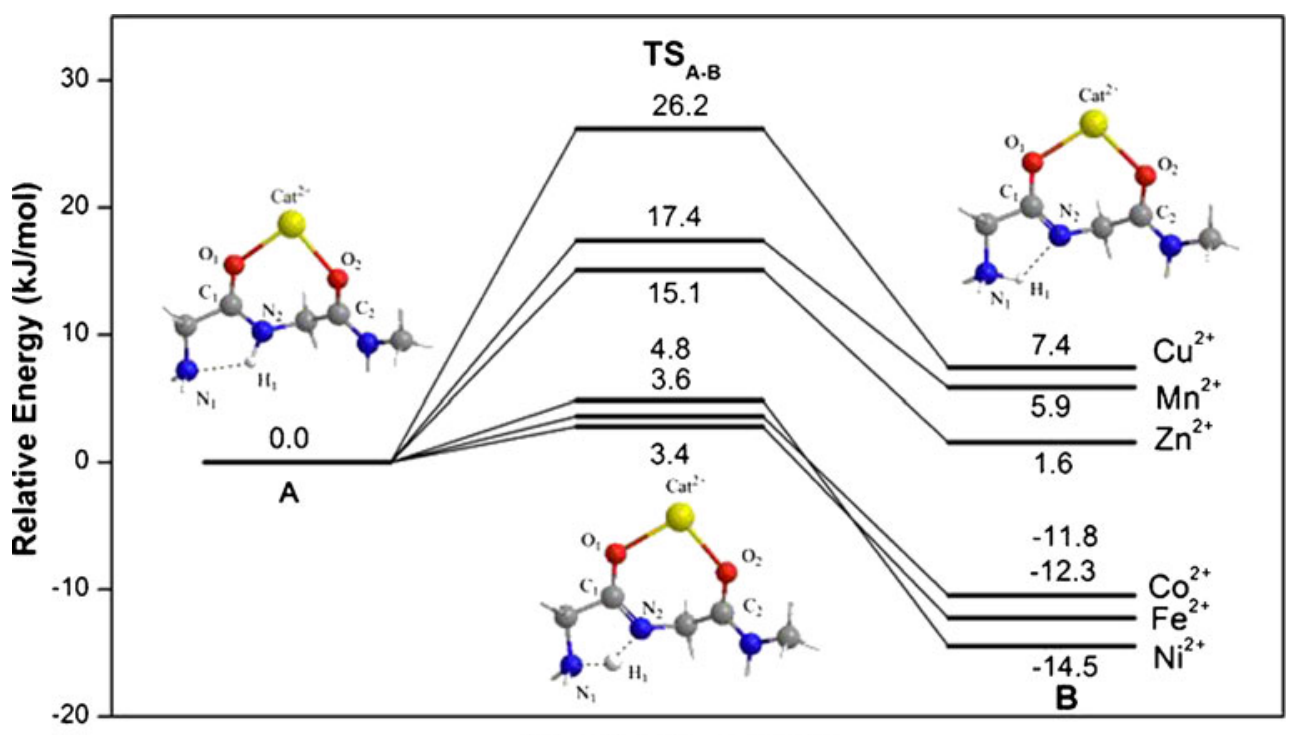

Reaction Coordinate

Scheme 1. Potential energy diagram associated with the deprotonation reactions of first row transition metal ions adducted $\mathrm{N}$-methyl glycyl-glycinamide. Single point energy calculated at the B3LYP/LANL2DZ+6-311++G(3df,2p) based on the structures optimized at B3LYP/LANL2DZ+6-31++G(d,p) level. The scale factor for ZPE is 0.961 
their corresponding charge reduced monocations are low spin with more than one of the $3 \mathrm{~d}$ orbitals doubly occupied (where low spin refer to ${ }^{3} \mathrm{~F}$ and ${ }^{2} \mathrm{D}$, as compared to the $\mathrm{s}$ occupation of the excited state ${ }^{5} \mathrm{~F}\left(4 \mathrm{~s}^{1} 3 \mathrm{~d}^{7}\right)$ and ${ }^{4} \mathrm{~F}\left(4 \mathrm{~s}^{1} 3 \mathrm{~d}^{8}\right)$ for $\mathrm{Co}^{+}$and $\mathrm{Ni}^{+}$, respectively). The ground state of $\mathrm{Fe}^{+}$is ${ }^{6} \mathrm{D}$ $\left(4 \mathrm{~s}^{1} 3 \mathrm{~d}^{6}\right)$, such that the $4 \mathrm{~s}$ orbital should be occupied by electron injection as the case of $\mathrm{Mn}^{2+}$ and $\mathrm{Zn}^{2+}$. However, free $\mathrm{Fe}^{+}$has a ${ }^{4} \mathrm{~F}\left(3 \mathrm{~d}^{7}\right)$ excited state that lies only $0.25 \mathrm{eV}$ above the ground state. It has been shown that $\mathrm{Fe}^{+}\left({ }^{4} \mathrm{~F}\right)$ is more reactive and has an energically more favorable electronic state in the ion-molecule reactions $[53,54]$. The switch of two different spin states for $\mathrm{Fe}^{+}$-complex can be approached by inter-system crossing [54]. Because $\mathrm{Fe}^{2+}$ adducted model peptides have more degrees of freedom as compared to those of small organic molecules, a longer-lived metalated intermediate might exist. The long-lived intermediates might allow a more frequent sampling of the crossing points. Therefore, the drastically different behavior of $\mathrm{Fe}^{2+}$ adducted RGGGVGGGR and NGGGWGGGN might be explained on the basis of the crossing of the potential energy surfaces. For $\mathrm{Fe}^{2+}$ adducted RGGGVGGGR, the incoming electron selectively neutralized the mobile proton of zwitterionic precursor ions to form radical and initiated the typical ECD dissociation channel. While for NGGGWGGGN, the incoming electron would be predominantly captured by the metal ions. The released energy was enough to induce the intersystem crossing between different potential energy surfaces. For $\mathrm{Co}^{+}$and $\mathrm{Ni}^{+}$, the excited states, $3 \mathrm{~d}^{n} 4 \mathrm{~s}^{1},(n=7$ and 8$)$ are unreactive and thus higher promotional energies are required. It is believed that the monocations favor a $3 \mathrm{~d}^{n}$ electronic configuration during the dissociation process. Unlike the high spin $3 \mathrm{~d}^{n} 4 \mathrm{~s}^{1}$ configurations, the $3 \mathrm{~d}^{n}$ configuration of these metal ions provides attractive bonding interactions between the $3 \mathrm{~d}$ orbitals and the peptides. Due to the high reactivity of electronic state with empty $d$ and $s$ orbitals for these metal ions, metal ions-electron recombination followed by fragmentation becomes more competitive than the proton-electron recombination. The incoming electron is believed to be trapped by the metal ions. It is proposed that the metal ion-electron recombination process is responsible for generating fragment species other than $c-/ z$-type fragment ions. The fragment ions species observed for $\mathrm{Fe}^{2+}, \mathrm{Co}^{2+}$, and $\mathrm{Ni}^{2+}$ were quite different as compared to those observed in spectra of protonated and alkaline earth metal ions adducted peptides.
ECD behavior of $\mathrm{Cu}^{2+}$ metalated model peptides is quite different from those of the other metal ions studied. Metalated $b$-/y-type fragment ions were exclusively generated. As proposed previously [25], due to the $3 \mathrm{~d}^{9}$ electronic configuration, the complexes favored reduction of $\mathrm{Cu}^{2+}$ to $\mathrm{Cu}^{+}$, which formed a closed $\mathrm{d}$ shell system in the electron irradiation event. Another hypothesis was that $\mathrm{Cu}^{2+}$ was already reduced to $\mathrm{Cu}^{+}$in the precursor ions through an "internal" electron transfer before electron irradiation [26]. The incoming electron was captured by the peptide radical, rather than the metal ion. Further study of $\mathrm{Cu}(\mathrm{I})$ adducted peptides might provide additional information about the two mechanisms.

\section{Recombination of the Electron: Metal Ion or Proton}

Previously, Heck and co-workers [25] suggested that metal ions act as an initial site of electron capture; and the subsequent electron transfer and energy transfer were two competitive processes in the ECD experiments of metalated oxytocin. The electron transfer process for $\mathrm{Co}^{2+}, \mathrm{Ni}^{2+}$, and $\mathrm{Zn}^{2+}$ adducted complexes leads to formation of hydrogen radical and causes typical ECD fragmentations. However, for the model peptides studied here, the ECD behavior of $\mathrm{Co}^{2+}$ and $\mathrm{Ni}^{2+}$ adducted peptide shared some similarities, but quite different from that of $\mathrm{Zn}^{2+}$. Håkansson et al. proposed that the ECD behavior correlated with second ionization energy (IE2) of the metal atom [26]. They explained the different fragmentation pattern for $\mathrm{Co}^{2+}$ and $\mathrm{Ni}^{2+}$ metalated SubP trications by their higher second ionization energies. The proposed correlation between IE2 of metal ions and ECD behavior of metalated peptide seemed to be logical. Follow this assumption, more typical I fragment ions should be observed for $\mathrm{Co}^{2+}$ adducted peptides as compared to that of $\mathrm{Zn}^{2+}$. In contrast to the prediction, the type II fragment ions dominated the products in the ECD spectrum of $\mathrm{Co}^{2+}$ adducted NGGGWGGGN. This implies that the IE2 of metal atom might not be the decisive factor for the ECD behavior of metal ion adducted model peptides. In addition, previous theoretical results indicated that the recombination energy of metal ions would be largely decreased by ligand coordination as compared to the IE2 of free metal atom [30, 31]. It was therefore not meaningful to directly correlate the

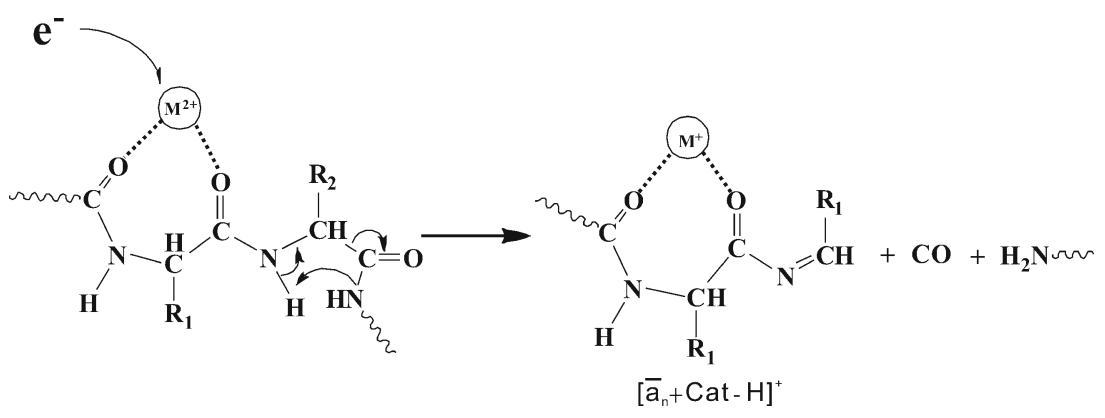

Scheme 2. Proposed mechanism for the formation of metalated $a$-type fragment ions in the ECD of metalated peptides 

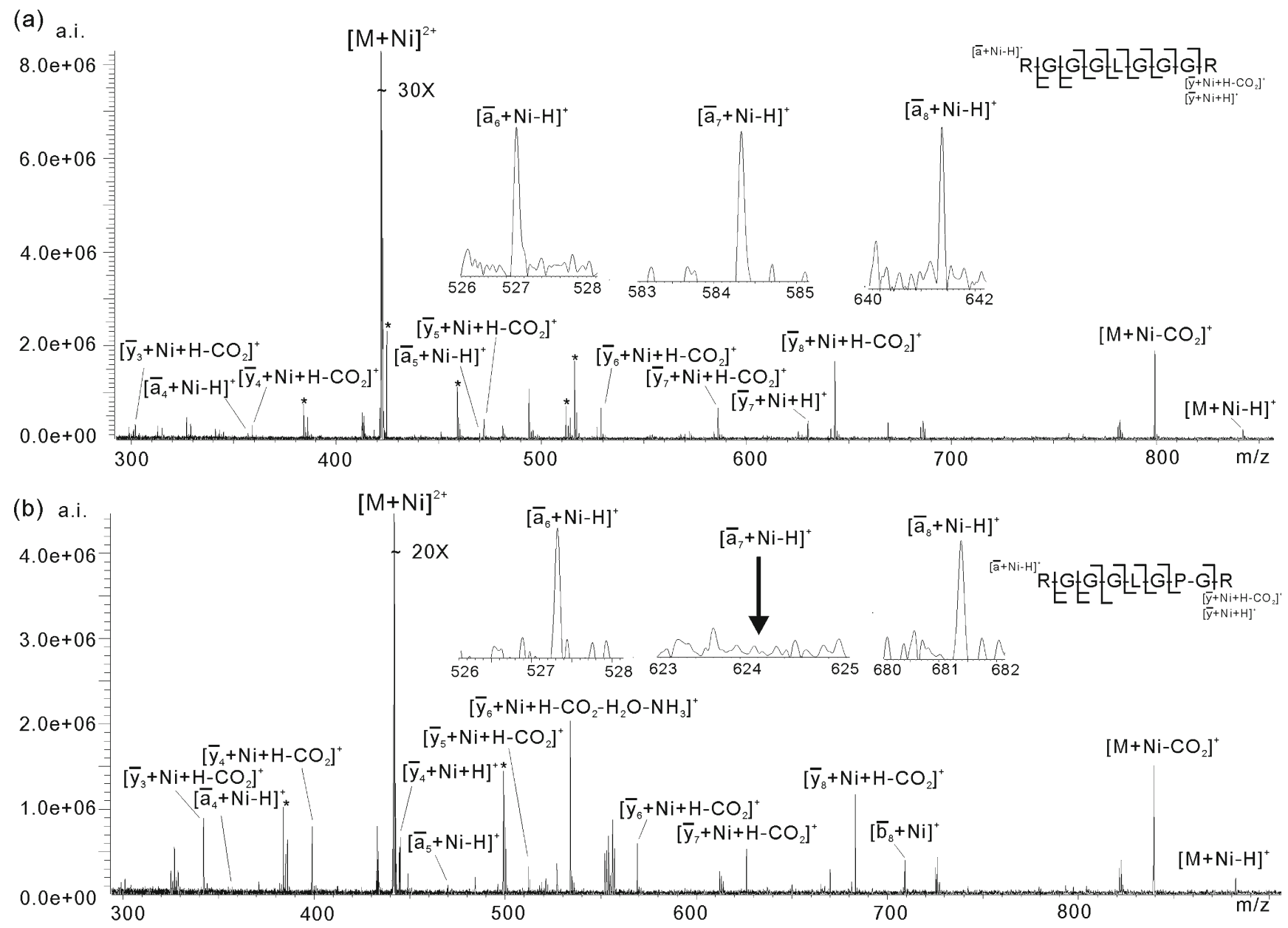

Figure 5. Typical ECD mass spectra of $\mathrm{Ni}^{2+}$ adducted (a) RGGGLGGGR and (b) RGGGLGPGR

ECD fragmentation of metalated peptides with the IE2 of free metal atom.

Considering the changes of coordination environment of metal ion before and after charge reduction, the energetic of metal ion-electron recombination is governed by

$$
\Delta \mathrm{H}_{\mathrm{et}}=\mathrm{H}(\mathrm{Cat}(\mathrm{II}))-\Delta \mathrm{H}_{\mathrm{sov}}\left(\mathrm{Cat}^{2+/+}+\mathrm{M}\right)
$$

$\mathrm{H}(\mathrm{Cat}(\mathrm{II}))$ is the second ionization enthalpy of free metal atom, and $\Delta \mathrm{H}_{\mathrm{sov}}\left(\mathrm{Cat}^{2+} I^{+}+\mathrm{M}\right)$ is the adiabatic enthalpy difference of the solvating free $\mathrm{Cat}^{2+}$ and $\mathrm{Cat}^{+}$ions by the peptide. The interaction of transition metal monocation and peptide is controlled by a balance between ion-dipole attraction and Pauli repulsion between the metal ion and the ligated groups of the peptide. As discussed above, for $\mathrm{Mn}^{2+}$ and $\mathrm{Zn}^{2+}$, the occupation of $4 \mathrm{~s}$ orbital of metal ions after charge reduction would increase the ionic radius of the metal ions. It will decrease the ion-dipole attraction and increase the Pauli repulsion between the metal ions and coordinated peptides, thus leading to a large change of solvation energy, $\Delta \mathrm{H}_{\mathrm{sov}}\left(\mathrm{Cat}^{2+} /^{+}+\mathrm{M}\right)$. Energetically, the metal ion-electron recombination might not be favorable if the second ionization energy of the metal atom was not high enough to compensate the change in solvation energy. For other metal ions, adoption of incoming electron into the partially occupied $3 \mathrm{~d}$ orbital would not substantially increase the ionic radius. On the other hand, the attractive bonding interactions between the $3 \mathrm{~d}$ orbital and the peptides would be enhanced. These lead to a relatively small change of solvation energy. The metal ion-electron recombination becomes more feasible.

If the fragment ions were formed by energy transfer after the electron being captured by the metal ions, the resulting fragment types upon ECD and CID should be to some extent similar to each other. Gross and co-workers [55] found that $a$-type fragments were the dominant products in $\mathrm{Co}^{2+}$ and $\mathrm{Ni}^{2+}$-peptide complexes $\left([\mathrm{M}+\mathrm{Cat}-\mathrm{H}]^{+}\right)$under CID conditions. They observed abundant metalated $a$-type fragment ions in CID of $\mathrm{Fe}^{2+}$ adducted cysteine-containing peptides [56]. Consistent with our observations, metalated $a$ type fragment ions were observed in the ECD of $\mathrm{Fe}^{2+}, \mathrm{Co}^{2+}$, and $\mathrm{Ni}^{2+}$-metalated NGGGWGGGN. Russell and co-workers found that the principal decay products were metalated $b$ and $a$-type fragment ions in the metastable dissociation of $\mathrm{Cu}^{+}$adducted $\mathrm{N}$-terminal arginine containing peptide $[\mathrm{M}+$ $\mathrm{Cu}]^{+}$[57]. The ECD fragmentation of $\mathrm{Cu}^{2+}$ adducted model peptide resembled their findings. Wesdemiotis and co- 
workers investigated the post source decay (PSD) mass spectra of bradykinin (BK) related peptides complexed with $\mathrm{Co}^{2+}, \mathrm{Ni}^{2+}, \mathrm{Cu}^{+}$, and $\mathrm{Zn}^{2+}$ [58]. The primary fragment ions were also metalated $a-, b$-, and $y$-type ions. The similarities between the ECD and vibrationally excited methods indicated that the "slow-heating" ECD fragment ions might be induced by energy transfer after metal ions reduction. In addition, no $c-/ z$-type fragment ions were generated in either PSD of $[\mathrm{M}+\mathrm{Zn}-\mathrm{H}]^{+}[58]$ or CID of $[\mathrm{M}+\mathrm{Zn}]^{2+}[59,60]$. The dominant fragment ions were the usual "slow-heating" $b$-/y-type fragment ions. This implies that the ECD fragments of model peptides adducted with $\mathrm{Mn}^{2+}$ or $\mathrm{Zn}^{2+}$ were induced by the radical formed after electron capture, rather than via vibrational excitation.

We propose that the typical ECD fragment ions are formed by usual ECD mechanism. Electron capture by metal ions and electron capture by mobile proton and/or amide $\pi^{*}$ of the peptide are two competitive processes. This argument can be supported by comparing the PIAs of various fragment ions of model peptides metalated with the same metal ions. As discussed above, comparing RGGGWGGGR and NGGGWGGGN, the main difference between the two types of peptides is the populations of isomers of precursor ions. For the metalated RGGGWGGGR, the population of zwitterionic structures is believed to be higher than that of NGGGWGGGN. This may provide higher possibilities for the usual ECD channel and more type I fragment ions were generated, as shown in Figure 4.

\section{Formation of Metalated a-/y-Type Fragment Ions}

Formation of metalated $a$ - and $y$-ions in the ECD spectra of $\mathrm{Fe}^{2+}, \mathrm{Co}^{2+}$, and $\mathrm{Ni}^{2+}$ adducted peptides shows a clear tunable effect of metal ion on the ECD fragmentation. It indicates that choosing different transition metal ions might "toggle" the major dissociation channels. From a survey of the literatures, three fragmentation pathways have been proposed to account for backbone $\mathrm{C}-\mathrm{C}$ cleavage. One is the amide hydrogen migration pathway (shown in Scheme 2) $[56,57]$. The second involves metal ions insertion into the $\mathrm{C}-\mathrm{C}$ bond, followed by amide hydrogen transfer by metal ions [61, 62]. The third is the $C_{\beta}$ hydrogen migration from side chain of residue [57]. In order to check the function of adjacent amide hydrogen for the formation of metalated $a$ type fragment ions, ECD of RGGGLGPGR, with one glycine replaced by proline, was performed. Figure 5 shows the ECD spectra of $\mathrm{Ni}^{2+}$ adducted RGGGLGGGR and RGGGLGPGR. The $\left[\bar{a}_{7}+\mathrm{Ni}-\mathrm{H}\right]^{+}$observed in the ECD of $\mathrm{Ni}^{2+}$ adducted RGGGLGGGR was not observed in the corresponding spectrum of RGGGLGPGR. While the other $a$-type fragment ions were observed in both spectra. This implies that the amide hydrogen is important for the formation of metalated $a$-type fragment ions in the ECD of $\mathrm{Ni}^{2+}$ adducted peptides.

It is important to note that the shift of fragment types from $a$ - $y$-ions to $b$ - $y$-ions for $\mathrm{Ni}^{2+}$ to $\mathrm{Cu}^{2+}$ adducted peptides. The change of fragment types might be caused by the extent of polarization of the amide hydrogen. High occupancy of the d-orbitals can better shield the nuclear charge. The nearby carbonyl groups experience lower attractive forces from the metal ion and thereby leading to a longer distance between the metal ion centre and the carbonyl oxygen. The interaction becomes energetically less favorable. A longer distance between the metal ion center and the carbonyl oxygen implies lower polarization of the amide hydrogen and thus lowering the extent of $a-y$ - ion formation. Being a competitive dissociation channel, formation of $b-/ y$ - ions becomes a dominant process.

Apart from the model peptides, we also studied the ECD behavior of metalated Bradykinin, RPPGFSPFR, as a representative for linear bio-active peptides. Similar observations obtained using the model peptide RGGGVGGGR were generated for all the selected metal ions. The $c-/ z$-type fragment ions formed by cleavage of $\mathrm{N}$-terminus of proline residues and the metalated $a$-type formed by cleavage the $\mathrm{C}$ terminus $\mathrm{C}-\mathrm{C}$ bond of proline residues were not observed due to the cyclic nature of the proline residues.

\section{Conclusions}

ECD of the first row divalent transition metal ions adducted model peptides shows a progressive shift in backbone fragmentation. Based on the ECD tandem mass spectra of a series of metalated model peptides, it was believed that the electronic configurations of metal ions governed the ECD behavior of model peptides. Electron captured by proton and electron captured by metal ion are two competitive channels. For $\mathrm{Mn}^{2+}$ and $\mathrm{Zn}^{2+}$ with half and fully filled $\mathrm{d}$ shells, the usual ECD fragmentation behavior of metalated peptides was rationalized by electron-proton recombination. For the other metal ions, including $\mathrm{Fe}^{2+}, \mathrm{Co}^{2+}, \mathrm{Ni}^{2+}$, and $\mathrm{Cu}^{2+}$, with partially filled $\mathrm{d}$ shell, the formation of "slow-heating" type of fragment ions were caused by energy transfer after electron-metal ion recombination.

\section{Acknowledgments}

The authors acknowledge that the work described in this paper was fully supported by a grant from the Research Grants Council of the Hong Kong Special Administrative Region, China (project no. 400209). The calculations were carried out in part using the ORION calculation workstation in the Information Technology Service Center (ITSC) at the Chinese University of Hong Kong. The authors thank the ITSC for generous allocation of computing time and space of the system.

\section{References}

1. Zubarev, R.A., Kelleher, N.L., McLafferty, F.W.: Electron capture dissociation of multiply charged protein cations. A nonergodic process. J. Am. Chem. Soc. 120, 3265-3266 (1998)

2. Zubarev, R.A., Horn, D.M., Fridriksson, E.K., Kelleher, N.L., Kruger, N.A., Lewis, M.A., Carpenter, B.K., McLafferty, F.W.: Electron capture dissociation for structural characterization of multiply charged protein cations. Anal. Chem. 72, 563-573 (2000) 
3. Cooper, H.J., Håkansson, K., Marshall, A.G.: The role of electron capture dissociation in biomolecular analysis. Mass Spectrom. Rev. 24, 201-222 (2005)

4. Little, D.P., Speir, J.P., Senko, M.W., O’Connor, P.B., McLafferty, F. W.: Infrared multiphoton dissociation of large multiply charged ions for biomolecule sequencing. Anal. Chem. 66, 2809-2815 (1994)

5. Woodlin, R.L., Bomse, D.S., Beauchamp, J.L.: Multiphoton dissociation of molecules with low power continuous wave infrared laser radiation. J. Am. Chem. Soc. 100, 3248-3250 (1978)

6. Jennings, K.R.: The changing impact of the collision-induced decomposition of ions on mass spectrometry. Int. J. Mass Spectrom. 200, 479493 (2000)

7. Biemann, K.: Sequencing of peptides by tandem mass spectrometry and high-energy collision-induced dissociation. Methods Enzymol. 193, 455-479 (1990)

8. Kjeldsen, F., Zubarev, R.: Secondary losses via $\gamma$-lactam formation in hot electron capture dissociation: A missing link to complete de novo sequencing of proteins? J. Am. Chem. Soc. 125, 6628-6629 (2003)

9. Kelleher, R.L., Zubarev, R.A., Bush, K., Furie, B., Furie, B.C., McLafferty, F.W., Walsh, C.T.: Localization of labile post-translational modifications by electron capture dissociation: The case of $\mathrm{O}$ carboxyglutamic acid. Anal. Chem. 71, 4250-4253 (1999)

10. Stensballe, A., Jensen, O.N., Olsen, J.V., Haselmann, K.F., Zubarev, R. A.: Electron capture dissociation of singly and multiply phosphorylated peptides. Rapid Commun. Mass Spectrom. 14, 1793-1800 (2000)

11. Shi, S.D.H., Hemling, M.E., Carr, S.A., Horn, D.M., Lindh, I., McLafferty, F.W.: Phosphopeptide/phosphoprotein mapping by electron capture dissociation mass spectrometry. Anal. Chem. 73, 19-22 (2001)

12. Hakansson, K., Cooper, H.J., Emmett, M.R., Costello, C.E., Marshall, A.G., Nilsson, C.L.: Electron capture dissociation and infrared multiphoton dissociation MS/MS of an N-glycosylated tryptic peptide to yield complementary sequence information. Anal. Chem. 73, 45304536 (2001)

13. Mirgorodskaya, E., Roepstorff, P., Zubarev, R.A.: Localization of Oglycosylation sites in peptides by electron capture dissociation in a fourier transform mass spectrometer. Anal. Chem. 71, 4431-4436 (1999)

14. Guan, Z.Q.: Identification and localization of the fatty acid modification in ghrelin by electron capture dissociation. J. Am. Soc. Mass Spectrom. 13, 1443-1447 (2002)

15. Breuker, K., Oh, H.B., Horn, D.M., Cerda, B.A., McLafferty, F.W.: Detailed unfolding and folding of gaseous ubiquitin ions characterized by electron capture dissociation. J. Am. Chem. Soc. 124, 6407-6420 (2002)

16. Oh, H., Breuker, K., Sze, S.K., Ge, Y., Carpenter, B.K., McLafferty, F. W.: Secondary and tertiary structures of gaseous protein ions characterized by electron capture dissociation mass spectrometry and photofragment spectroscopy. Proc. Natl. Acad. Sci. U. S. A. 99, 15863-15868 (2002)

17. Lin, C., Cournoyer, J.J., O'Connor, P.B.: Probing the gas-phase folding kinetics of peptide ions by IR activated DR-ECD. J. Am. Soc. Mass Spectrom. 19, 780-789 (2008)

18. Zubarev, R.A., Haselmann, K.F., Budnik, B., Kjeldsen, F., Jensen, F.: Towards an understanding of the mechanism of electron-capture dissociation: A historical perspective and modern ideas. Eur. J. Mass Spectrom. 8, 337-349 (2002)

19. Fung, Y.M.E., Adams, C.M., Zubarev, R.A.: Electron ionization dissociation of singly and multiply charged peptides. J. Am. Chem. Soc. 131, 9977-9985 (2009)

20. Chan, W.Y.K., Chan, T.W.D.: Natural structural motifs that suppress peptide ions fragmentation after electron capture. J. Am. Soc. Mass Spectrom. 21, 1235-1244 (2010)

21. Sohn, C.H., Chung, C.K., Yin, S., Ramachandran, P., Loo, J.A., Beauchamp, J.L.: Probing the mechanism of electron capture and electron transfer dissociation using tags with variable electron affinity. J. Am. Chem. Soc. 113, 5444-5459 (2009)

22. Eller, K., Schwarz, H.: Organometallic chemistry in gas phase. Chem. Rev. 91, 1121-1177 (1991)

23. Iavarone, A.T., Paech, K., Williams, E.R.: Effects of charge state and cationizing agent on the electron capture dissociation of a peptide. Anal. Chem. 76, 2231-2238 (2004)

24. Fung, Y.M.E., Liu, H., Chan, T.W.D.: Electron capture dissociation of peptides metalated with alkaline-earth metal ions. J. Am. Soc. Mass Spectrom. 17, 757-771 (2006)

25. Kleinnijenhuis, A.J., Mihalca, R., Heeren, R.M.A., Heck, A.J.R.: Atypical behavior in the electron capture induced dissociation of biologically relevant transition metal ion complexes of the peptide hormone oxytocin. Int. J. Mass Spectrom. 253, 217-224 (2006)

26. Liu, H.C., Håkansson, K.: Divalent metal ion-peptide interactions probed by electron capture dissociation of trications. J. Am. Soc. Mass Spectrom. 17, 1731-1741 (2006)

27. Yuri, B.E.V., Palmblad, M., Dallebout, H., Heeren, R.M.A.: Electron capture dissociation of peptide hormone changes upon opening of the tocin ring and complexation with transition metal cations. Rapid Commun. Mass Spectrom. 23, 31-38 (2009)

28. Feketeová, L., Ryzhov, V., O'Hair, R.A.J.: Comparison of collisionversus electron-induced dissociation of Pt (II) ternary complexes of histidine- and methionine-containing peptides. Rapid Commun. Mass Spectrom. 23, 3133-3143 (2009)

29. Chen, X., Chan, W.Y.K., Wong, P.S., Yeung, H.S., Chan, T.W.D.: Formation of peptide radical cations $\left(\mathrm{M}^{+} \bullet\right)$ in electron capture dissociation of peptides adducted with group IIB metal ions. J. Am. Soc. Mass Spectrom. 22, 233-244 (2011)

30. Turecek, F., Jones, J.W., Holm, A.I.S., Panja, S., Nielsen, S.B., Hvelplund, P.: Transition metals as electron traps. I. Structures, energetics, electron capture, and electron-transfer-induced dissociations of ternary copper-peptide complexes in the gas phase. J. Mass. Spectrom. 44, 707-725 (2009)

31. Turecek, F., Jones, J.W., Holm, A.I.S., Panja, S., Nielsen, S.B., Hvelplund, P.: Transition metals as electron traps. II. Structures, energetics and electron transfer dissociations of ternary $\mathrm{Co}, \mathrm{Ni}$ and $\mathrm{Zn}$-peptide complexes in the gas phase. J. Mass. Spectrom. 44, 15181531 (2009)

32. Kaczorowska, M.A., Cooper, H.J.: Electron capture dissociation and collision-induced dissociation of metal ion $\left(\mathrm{Ag}^{+}, \mathrm{Cu}^{2+}, \mathrm{Zn}^{2+}, \mathrm{Fe}^{2+}\right.$, and $\mathrm{Fe}^{3+}$ ) Complexes of polyamidoamine (PAMAM) dendrimers. J. Am. Soc. Mass Spectrom. 20, 674-681 (2009)

33. Liu, H.C., Håkansson, K.: Electron capture dissociation of tyrosine Osulfated peptides complexed with divalent metal cations. Anal. Chem. 78, 7570-7576 (2006)

34. Elkind, J.L., Armentrout, P.B.: State-specific reactions of atomic transition-metal ions with $\mathrm{H} 2, \mathrm{HD}$, and D2: Effects of d orbitals on chemistry. J. Phys. Chem. 91, 2045-2047 (1987)

35. Lau, R.L.C., Jiang, J.Z., Ng, D.K.P., Chan, T.W.D.: Fourier transform ion cyclotron resonance studies of Lanthanide(III) Porphyrin-Phthalocyanine heteroleptic sandwich complexes by using electrospray ionization. J. Am. Soc. Mass Spectrom. 8, 161-169 (1997)

36. Fong, K.W.Y., Chan, T.W.D.: A novel nonmetallized tip for electrospray mass spectrometry at nanoliter flow rate. J. Am. Soc. Mass Spectrom. 10, 72-75 (1999)

37. Chan, T.W.D., Duan, L., Sze, T.P.: Accurate mass measurements for peptide and protein mixtures by using matrix-assisted laser desorption/ ionization fourier transform mass spectrometry. Anal. Chem. 74, 52825289 (2002)

38. Chan, T.W.D., Ip, W.H.H.: Optimization of experimental parameters for electron capture dissociation of peptides in a fourier transform mass spectrometer. J. Am. Soc. Mass Spectrom. 13, 1396-1406 (2002)

39. Frisch, M.J., Trucks, G.W., Schlegel, H.B., Scuseria, G.E., Robb, M.A., Cheeseman, J.R., Montgomery Jr., J.A., Vreven, T., Kudin, K.N., Burant, J.C., Millam, J.M., Iyengar, S.S., Tomasi, J., Barone, V., Mennucci, B., Cossi, M., Scalmani, G., Rega, N., Petersson, G.A., Nakatsuji, H., Hada, M., Ehara, M., Toyota, K., Fukuda, R., Hasegawa, J., Ishida, M., Nakajima, T., Honda, Y., Kitao, O., Nakai, H., Klene, M., Li, X., Knox, J.E., Hratchian, H.P., Cross, J.B., Adamo, C., Jaramillo, J., Gomperts, R., Stratmann, R.E., Yazyev, O., Austin, A.J., Cammi, R., Pomelli, C., Ochterski, J.W., Ayala, P.Y., Morokuma, K., Voth, G.A., Salvador, P., Dannenberg, J.J., Zakrzewski, V.G., Dapprich, S., Daniels, A.D., Strain, M.C., Farkas, O., Malick, D.K., Rabuck, A.D., Raghavachari, K., Foresman, J.B., Ortiz, J.V., Cui, Q., Baboul, A.G., Clifford, S., Cioslowski, J., Stefanov, B.B., Liu, G., Liashenko, A., Piskorz, P., Komaromi, I., Martin, R.L., Fox, D.J., Keith, T., Al-Laham, M.A., Peng, C.Y., Nanayakkara, A., Challacombe, M., Gill, P.M.W., Johnson, B., Chen, W., Wong, M.W., Gonzalez, C., Pople, J.A.: Gaussian 03, Revision D.01. Gaussian, Inc, Wallingford (2004)

40. Becke, A.D.: A new mixing of hartree-fock and local density-functional theories. J. Chem. Phys. 98, 1372-1377 (1993)

41. Becke, A.D.: Density-functional thermochemistry. III. The role of exact exchange. J. Chem. Phys. 98, 5648-5652 (1993)

42. Lee, C., Yang, W., Parr, R.C.: Development of the Colle-Salvetti correction-energy formula into a function of the electron density. Phys. Rev. B. 37, 785-789 (1988) 
43. Hay, P.J., Wadt, W.R.: Ab intio effective core potentials for molecular calculations. Potenitals for the transition metal atoms $\mathrm{Sc}$ to $\mathrm{Hg}$. J. Chem. Phys. 82, 270-283 (1985)

44. Wadt, W.R., Hay, P.J.: Ab initio effective core potentials for molecular calculations. Potentials for main group elements $\mathrm{Na}$ to Bi. J. Chem. Phys. 82, 284-298 (1985)

45. Hay, P.J., Wadt, W.R.: Ab intio effective core potentials for molecular calculations. Potentials for $\mathrm{K}$ to $\mathrm{Au}$ including the outermost core orbitals. J. Chem. Phys. 82, 299-310 (1985)

46. Sovago, I., Osz, K.: Metal Ion Selectivity of Oligopeptides. Dalton Trans. 3841-3854 (2006)

47. Sigel, H., Martin, R.B.: Coordinating properties of the amide bondstability and structure of metal-ion complexes of peptides and related ligands. Chem. Rev. 82, 385-426 (1982)

48. Rulisek, L., Vondrasek, J.: Coordination geometries of selected transition metal ions $\left(\mathrm{Co}^{2+}, \mathrm{Ni}^{2+}, \mathrm{Cu}^{2+}, \mathrm{Zn}^{2+}, \mathrm{Cd}^{2+}\right.$, and $\left.\mathrm{Hg}^{2+}\right)$ in metalloproteins. J. Inorg. Biochem. 71, 115-127 (1998)

49. Wong, C.K.L., Chan, T.W.D.: Cationization processes in matrix-assisted laser desorption/ionization mass spectrometry: Attachment of divalent and trivalent metal ions. Rapid Commun. Mass Spectrom. 11, 513-519 (1997)

50. Syrstad, E.A., Turecek, F.: Towards a general mechanism of electron capture dissociation. J. Am. Soc. Mass Spectrom. 16, 208-224 (2005)

51. Rimola, A., Constantino, E., Rodriguez-Santiago, C., Sodupe, M. Binding properties of $\mathrm{Cu}^{+} /{ }^{2+}-(\text { glycyl })_{n}$ glycine complexes $(n=1-3) . J$. Phys. Chem. A. 112, 3444-3453 (2008)

52. Constantino, E., Rimola, A., Sodupe, M., Rodriguez-Santiago, C.: Coordination of (glycyl) glycine complexes $(n=1-3)$ to $\mathrm{Co}^{+}$and $\mathrm{Co}^{2+}$. J. Phys. Chem. A 113, 8883-8892 (2009)

53. Armentrout, P.B.: Electronic state-specific transition metal ion chemistry. Annu. Rev. Phys. Chem. 41, 313-344 (1990)
54. Schröder, D., Shaik, S., Schwarz, H.: Two-state reactivity as a new concept in organometallic chemistry. Acc. Chem. Res. 33, 139-145 (2000)

55. Hu, P., Sorensen, C., Gross, M.L.: Influences of peptide side chain on the metal ion binding site in metal ion-cationized peptides: participation of aromatic rings in metal chelation. J. Am. Soc. Mass Spectrom. 6, 1079-1085 (1995)

56. Nemirovskiy, O.V., Gross, M.L.: Complexes of iron (II) with cysteinecontaining peptides in the gas phase. J. Am. Soc. Mass Spectrom. 7, 977-980 (1996)

57. Shields, S.J., Bluhm, B.K., Russell, D.H.: Fragmentation chemistry of $[\mathrm{M}+\mathrm{Cu}]^{+}$peptide ions containing an n-terminal arginine. J. Am. Soc. Mass Spectrom. 11, 626-638 (2000)

58. Cerda, B.A., Cornett, L., Wesdemiotis, C.: Probing the interaction of alkali and transition metal ions with bradykinin and its des-arginine derivatives via matrix-assisted laser desorption/ionization and postsource decay mass spectrometry. Int. J. Mass Spectrom. 193, 205-226 (1999)

59. $\mathrm{Hu}, \mathrm{P}$., Loo, J.A.: Gas-phase coordination properties of $\mathrm{Zn}^{2+}, \mathrm{Cu}^{2+}, \mathrm{Ni}^{2}$ ${ }^{+}$, and $\mathrm{Co}^{2+}$ with histidine-containing peptides. J. Am. Chem. Soc. 117, 11314-11319 (1995)

60. Hu, P., Loo, J.A., Smith, R.D.: Interaction of angiotensin peptides and zinc metal ions probed by electrospray ionization mass spectrometry. $J$. Am. Soc. Mass Spectrom. 5, 959-965 (1994)

61. Bouchonnet, S., Hoppilliard, Y., Ohanessian, G.: Formation and fragmentations of oganometallic complexes involving aliphatic $\alpha$-amino acids and transition metal cations - a plasma desorption mass spectrometry study. J. Mass Spectrom. 30, 172-179 (1995)

62. Rodriguez-Santiago, L., Sodupe, M., Tortajada: Gas-phase reactivity of $\mathrm{Ni}^{+}$with glycine. J. Phys. Chem. A. 105, 5340-5347 (2001) 